PRELIMINARY HYDROGEOLOGIC EVALUATION OF THE CINCINNATI ARCH REGION FOR UNDERGROUND HIGH-LEVEL RADIOACTIVE WASTE DISPOSAL, INDIANA, KENTUCKY, AND OHIO

By Orville B. Lloyd, Jr., and Robert W. Davis

U.S . GEOLOGICAL SURVEY

Water-Resources Investigations Report 88-4098

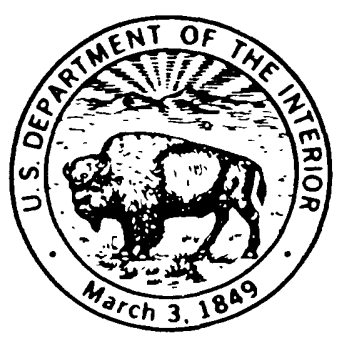

Raleigh, North Carolina 
DEPARTMENT OF THE INTERIOR

DONALD PAUL HODEL, Secretary

U.S. GEOLOGICAL SURVEY

Dallas L. Peck, Director

For additional information, contact:

Chief, Branch of Nuclear Waste Hydrology U.S. Geological Survey National Center, Mail Stop 410 12201 Sunrise Valley Drive

Reston, Virginia 22092

District Chief

U.S. Geological Survey

Post Office Box 2857

Raleigh, North Carolina 27602

Telephone: (919) 856-4510
Copies of this report can be purchased from:

Books and Open-File Reports U.S. Geological Survey Federal Center, Building 810 Box 25425

Denver, Colorado 80225 


\section{CONTENTS}

Page

Abstract. . . . . . . . . . . . . . . . . . . . . . . . . . . . 1

Introduction. . . . . . . . . . . . . . . . . . . . . . . . . . 2

Background . . . . . . . . . . . . . . . . . . . . . . . . . . . 2

Purpose and scope. . . . . . . . . . . . . . . . . . . . . . 4

Previous investigations. . . . . . . . . . . . . . . . . . . . . . 4

Acknowledgments. . . . . . . . . . . . . . . . . . . . . . . . . . 6

Methods of investigation. . . . . . . . . . . . . . . . . . . . . . 6

Hydrogeology of the sedimentary rocks . . . . . . . . . . . . . . . . . 8

General geology. . . . . . . . . . . . . . . . . . . . . . . . . . 8

Hydrogeologic framework. . . . . . . . . . . . . . . . . . . . . 14

Basal sandstone aquifer . . . . . . . . . . . . . . . . . 14

Potential confining unit. . . . . . . . . . . . . . . . . . . 17

Distribution and source of freshwater, saline water,

and brine. . . . . . . . . . . . . . . . . . . . . . . . . . . . 19

Ground-water occurrence and movement . . . . . . . . . . . . . . . 21

Relative hydrogeologic suitability of sedimentary rocks for high-

level radioactive waste disposal in buried crystalline rock . . . . . 27

Depth to crystalline rock. . . . . . . . . . . . . . . . . . . . 27

Dissolved-solids distribution in the basal sandstone aquifer . . . 28

Porosity distribution in the basal sandstone aquifer . . . . . . . 28

Thickness and distribution of shale and siltstone in the

potential confining unit . . . . . . . . . . . . . . . . . . . . 29

Distribution of faults . . . . . . . . . . . . . . . . . . . . . . 30

Summary and conclusions . . . . . . . . . . . . . . . . . . . . . 30

References. . . . . . . . . . . . . . . . . . . . . . . . . . 33

\section{ILLUSTRATIONS}

Plate 1. East-west hydrogeologic sections $A-A^{\prime}, B-B^{\prime}, C-C^{\prime}$, and $D-D^{\prime}$

in the Cincinnati arch region. . . . . . . . . . . . In pocket

2. North-south hydrogeologic sections $E-E^{\prime}, F-F^{\prime}$, and $G-G^{\prime}$ in

the Cincinnati arch region. . . . . . . . . . . . In pocket

Figures 1-4. Maps showing:

1. Location of the study area . . . . . . . . . . . . . 5

2. Location of selected wells and hydrogeologic

sections in the Cincinnati arch region . . . . . . 7 
3. Configuration of the top of the crystalline rock in the Cincinnati arch region. . . . . . . . . . . 9

4. Generalized geology and location of structural arches in the Cincinnati arch region . . . . . . . 11

5. Relation between stratigraphic units, the basal sandstone aquifer, and the potential confining unit. . . . . . . 15

6-9. Maps showing:

6. Average porosity of the basal sandstone aquifer in the Cincinnati arch region . . . . . . . . . . . . 16

7. Estimated distribution of thickest consecutive shale and siltstone beds in the potential confining unit in the Cincinnati arch region . . . . . . . . 18

8. Dissolved-solids concentration in the top part of the basal sandstone aquifer in the Cincinnati arch region. . . . . . . . . . . . . . 22

9. Land-surface altitude and streams and lakes in the Cincinnati arch region. . . . . . . . . . 25

\section{TABLES}

Table 1. Generalized correlation chart for rocks underlying parts of the Cincinnati arch region. . . . . . . . . . . . 13

2. Greatest consecutive thickness of shale and (or) siltstone in the potential confining unit. . . . . . . . . . . . . . 20

3. Record of selected wells. . . . . . . . . . . . . . . . 37 


\title{
PRELIMINARY HYDROGEOLOGIC EVALUATION OF THE CINCINNATI ARCH REGION FOR UNDERGROUND HIGH-LEVEL RADIOACTIVE WASTE DISPOSAL, INDIANA, KENTUCKY, AND OHIO
}

\author{
by Orville B. Lloyd, Jr., and Robert W. Davis
}

\begin{abstract}
Preliminary interpretation of hydrogeologic data indicates that some areas underlying eastern Indiana, north-central Kentucky, and western Ohio might be worthy of further study for potential disposal of high-level radioactive waste in Precambrian crystalline rocks buried beneath Paleozoic sedimentary rocks. The area of interest occurs where the top of the crystalline rock lies between about 2,000 feet and 3,500 feet below sea level or about 2,500 feet and 4,000 feet below land surface.
\end{abstract}

Data for five characteristics were evaluated. These include (1) depth to crystalline rock, (2) dissolved-solids distribution in the basal aquifer, (3) porosity distribution in the basal aquifer, (4) thickness of shale and siltstone beds within the potential confining interval, and (5) distribution of faults.

Maps of the characteristics show that (1) the largest areas of deepest potential burial and thickest sedimentary rock cover occur in eastern Indiana; (2) the highest concentrations of dissolved solids in the basal sandstone aquifer, indicating the most restricted circulation, are found in the southern part of the area around the Kentucky-Ohio state line and in southeastern Indiana; (3) the largest areas of lowest porosity in the basal sandstone aquifer, low porosity taken as an indicator of the lowest potential velocity for ground-water flow and contaminant migration, are found in northeastern Indiana and northwestern ohio, central and southeastern Indiana, and central Kentucky; (4) the thickest consecutive shale and siltstone beds within the potential confining interval are found in central Kentucky and eastern Indiana where their thickness exceeds 500 feet; (5) steeply dipping faults that form potential hydraulic connections between the crystalline rock, the basal sandstone aquifer, and the freshwater-circulation system occur on the boundaries of the study area mainly in central Kentucky and central Indiana. Collectively, these data indicate that the hydrogeology of the sedimentary rocks in the western part 
of the study area is more favorably suited than that in the remainder of the area for the disposal in buried crystalline-rock.

More detailed investigation will be necessary to test the preliminary findings and define the distribution of hydraulic head, hydraulic conductivity, and the direction(s) and rate(s) of ground-water flow in the saline-water and brine-bearing parts of the sedimentary section.

\section{INTRODUCTION}

\section{Background}

With a mandate from the Congress of the United States, the Department of Energy studied various waste-disposal and storage methods and physical environments to determine which are suited for the disposal of high-level radioactive wastes. One of the physical environments that received much attention and study was that found in crystalline igneous or metamorphic rocks that are exposed at land surface. The crystalline rocks were studied as potential sites for waste repositories because they (a) are easily mined, (b) are stable at high temperatures, (c) have a high thermal conductivity, (d) have low permeability when not fractured, and (e) are abundant on the continents (Bredehoeft and Maini, 1981).

Most crystalline rocks are fractured, however, and these fractures constitute a major disadvantage of the exposed crystalline-rock wastestorage environment. It is difficult, but not impossible considering recent advances in fractured-rock hydrology (International Association of Hydrogeologists, 1985), to predict the direction and rate of ground-water movement through a system of fractures because the orientation, spacing, interconnection, and continuity of the fractures are difficult to measure and characterize. Prediction of ground-water flow is important because ground-water transport would be one of the major vehicles for the migration of radionuclides from a repository (U.S. Geological Survey, 1980).

Fractures are less abundant and less well developed in deep-lying sedimentary rocks, and ground water primarily occurs in and moves through pores and intergranular openings between the rock particles. The orientation, spacing, and interconnection of the intergranular openings is 
regular and predictable; consequently, the rate and direction of groundwater movement in such sedimentary rocks is easy to characterize relative to that in fractured crystalline rocks, and the theory and methods of measurement are better established. In sedimentary rock under favorable hydrogeologic conditions, the flow paths are long and the flow rates are slow in the deep subsurface. Also, in many places, at depth sedimentary rocks contain water with elevated concentrations of dissolved solids, 10,000 $\mathrm{mg} / \mathrm{L}$ (milligrams per liter) or more, which minimizes the possibility of human intrusion. Pointing out these facts, Bredehoeft and Maini (1981) proposed the buried crystalline-rock concept in which a repository for nuclear waste might be developed in crystalline rock that is buried beneath a thick blanket of sedimentary rock. They emphasize that, with this approach, the minability, thermal conductivity, and other favorable properties of the crystalline rock can be combined with the predictability of ground-water movement in the overlying sedimentary rocks. Lack of data needed to characterize the flow system in the deep-lying sedimentary rock most likely will be the major disadvantage to the buried crystalline rock waste-storage environment.

The buried crystalline-rock concept was endorsed by the National Academy of Sciences in 1983 as worthy of further consideration. Thus, a study was conducted by the U.S. Geological Survey (Davis, 1984) to determine the regions in the eastern part of the United States where the conditions described by Bredehoeft and Maini (1981) exist.

Davis (1984) used the following four criteria to summarize and describe the hydrogeologic conditions pertinent to the "thick blanket of sedimentary rocks" that Bredehoeft and Maini (1981) proposed for their buried crystalline rock concept:

1. The top of the crystalline rock is 1,000 to 4,000 ft (feet) below land surface.

2. The crystalline rock is overlain by sedimentary rock whose lowermost part, at least, contains ground water having a dissolvedsolids concentration of $10,000 \mathrm{mg} / \mathrm{L}$ or more.

3. Shale or clay confining beds overlie the aquifer containing water with dissolved-solids concentrations of $10,000 \mathrm{mg} / \mathrm{L}$ or more. 
4. The flow system in the saline-water aquifer is known or determinable from presently available data.

Application of these criteria in the eastern part of the United States showed two regions that meet most of the criteria and are suitable for further study: (1) parts of Indiana, Ohio, and Kentucky, underlain by a well-known geologic structure called the Cincinnati arch, and (2) parts of the Atlantic Coastal Plain as described by Lloyd, Larson, and Davis (1985).

The Cincinnati arch region is the subject of this report. The study area includes about $29,000 \mathrm{mi}^{2}$ (square miles), of which 62 percent lies in western Ohio, 24 percent in central and eastern Indiana, and the remaining 14 percent lies in north-central Kentucky (fig. 1).

\section{Purpose and Scope}

The purpose of this report is to summarize available information and to evaluate the hydrogeology of the Paleozoic sedimentary rocks in the Cincinnati arch area relevant to the suitability for disposal of high-level radioactive waste in crystalline rock underlying the area. Emphasis is on those parts of the Paleozoic sedimentary rocks overlying the Cincinnati arch that best meet the conditions outlined by Davis (1984).

Five general characteristics were used for the preliminary evaluation of the hydrogeologic suitability of the sedimentary rocks for the application of the buried crystalline-rock concept: (1) depth to crystalline rock, (2) distribution of dissolved solids in water in the basal sandstone aquifer, (3) distribution of porosity in the basal sandstone aquifer, (4) thickness of shale and siltstone within the potential confining unit, and (5) distribution of faults. These characteristics were appraised from a study of geophysical-and lithologic-log data from various state agencies and well-log service companies, and from data published in reports of previous investigations.

\section{$\underline{\text { Previous Investigations }}$}

The many useful publications that describe the geologic and hydrologic characteristics of the Paleozoic rocks in the Cincinnati arch region include 


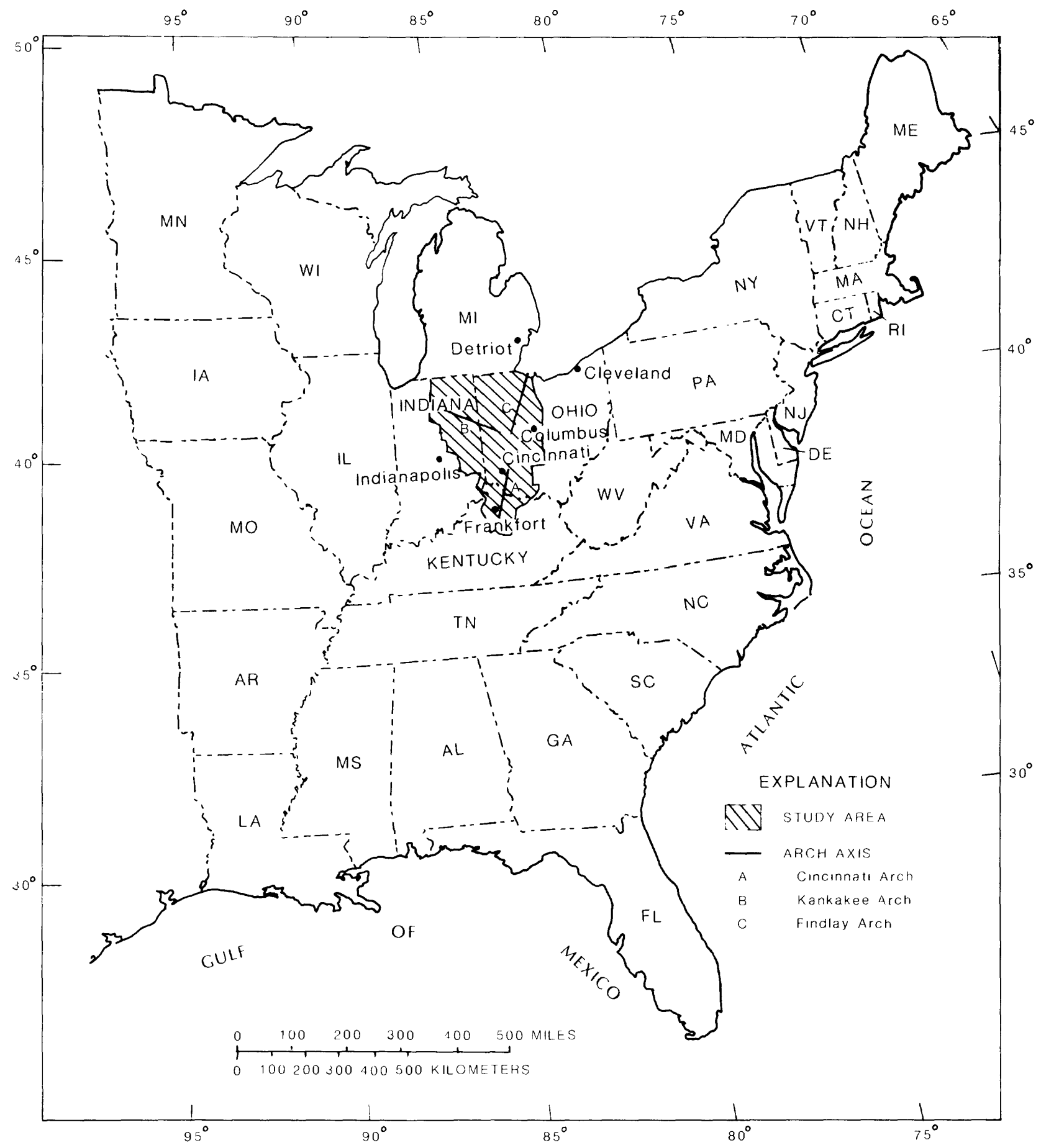

Figure 1.--Location of the study area. 
published reports by Stout and others (1932), Bownocker (1947), Lamborn (1952), McGuire and Howel1 (1963), Hopkins (1966), Owens (1967), Indiana Geological Survey (1970), Dawson (1971), Clifford (1973), Janssens (1973), Bloyd (1974), Ohio River Valley Water Sanitation Commission (ORSANCO, 1974 and 1976), Harris (1975), Dever and others (1977), American Association of Petroleum Geologists (1978), Becker and others (1978), Weist (1978), McDowell and others (1981), Keller (1983), Davis (1984), and Shaver (1985).

\section{Acknowledgments}

Thanks are due the Indiana Geological Survey, the Kentucky Geological Survey, and the Ohio Division of Geological Survey for providing information on selected wells in the study area. Also, the authors wish to acknowledge Albert M. La Sala, Jr. (U.S. Geological Survey, Columbus, Ohio), for his technical assistance regarding the reliability and use of hydraulic-head data from Clifford (1973) and water-quality data from the Ohio River Valley Water Sanitation Commission (ORSANCO 1976).

\section{METHODS OF INVESTIGATION}

This investigation consisted of a compilation, analysis, and synthesis of pertinent geologic and hydrologic data available from published reports; from commercial well-data companies; and from the Indiana Geological Survey, the Kentucky Geological Survey, and the Ohio Division of Geological Survey. The published data were taken at face value to be representative of existing hydrogeologic conditions in the study area. The thickness of the confining material (shale and siltstone beds) overlying the basal sandstone aquifer was estimated from published data and from a study by the authors of available lithologic and geophysical logs. Data from the report by the Ohio River Valley Water Sanitation Commission (ORSANCO, 1976) was particularly useful for this investigation.

Ninety of the deepest wells drilled in the area were selected as a keywe11 network to illustrate the kinds of well data that are available for the Paleozoic sedimentary rocks. The distribution of these wells is shown on figure 2 and the pertinent data for these wells are listed in table 3 ( $p$. 37). Seventy-five percent of these key wells have been drilled through the entire sedimentary rock section to the underlying crystalline rocks, and all 


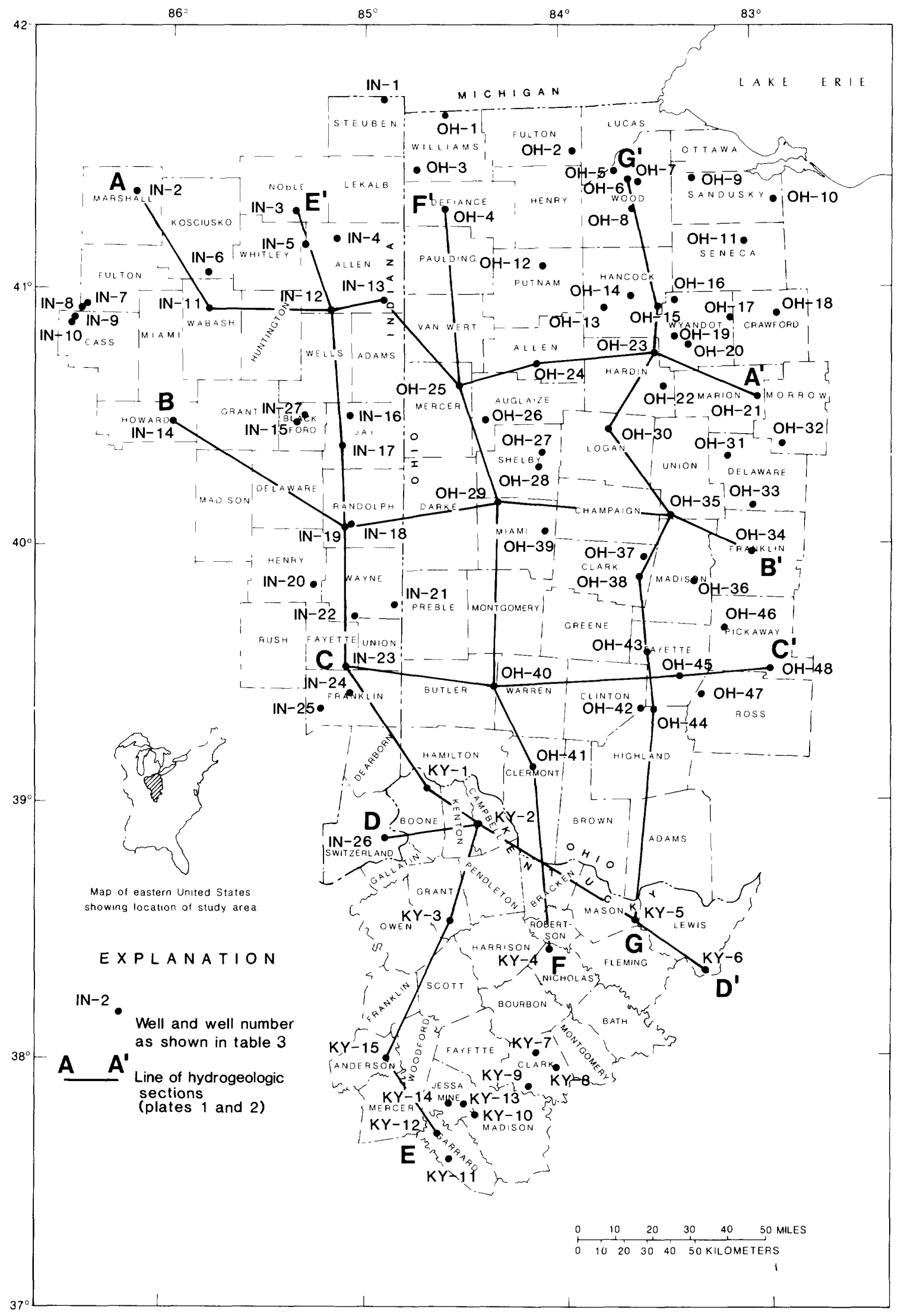

Figure 2.--Location of selected wells and hydrogeologic sections in the Cincinnati arch region. 
the wells provided data necessary to help define the hydrogeology in the area. Seven cross sections were constructed from the data and are used to show the general hydrogeologic conditions at selected places throughout the study area (fig. 2).

The depth to crystalline rock, distribution of dissolved-solids concentration and porosity in the basal aquifer, thickness and distribution of confining shale and siltstone beds within the potential confining unit overlying the basal aquifer, and the distribution of faults are the characteristics that were selected to summarize and evaluate the hydrogeologic suitability of the sedimentary rocks for the disposal of highlevel radioactive waste in the underlying crystalline rock. Maps of these characteristics were prepared and the relation between the long-term isolation of high-level radioactive waste and each characteristic is discussed individually.

\section{HYDROGEOLOGY OF THE SEDIMENTARY ROCKS}

An understanding of the hydrogeology of the sedimentary rocks in the area is important to help define the potential suitability for the application of the buried crystalline-rock concept to nuclear-waste disposal. The rock types, characteristics and relation to one another, and the structures that are found within and are defined by the distribution of the rocks, are important factors that control the occurrence, movement, and distribution of the fresh and saline ground water in the rocks. Thus, these factors would have a major role in the control of the migration of any radionuclides that might find their way into the ground water from a waste repository developed in underlying crystalline rock.

\section{General Geology}

The crystalline rocks that lie beneath the area are composed of igneous and metamorphic rocks of Precambrian age (Shaver, 1985) and form the basement complex upon which the Paleozoic sedimentary rocks were deposited. Common crystalline rocks include granite, rhyolite, basalt, granite gneiss, schist, and amphibolite. The general configuration of the crystalline-rock surface is shown in figure 3. The altitude of this surface ranges from less than 2,000 ft below sea level in western Ohio to as much as 6,000 ft in 


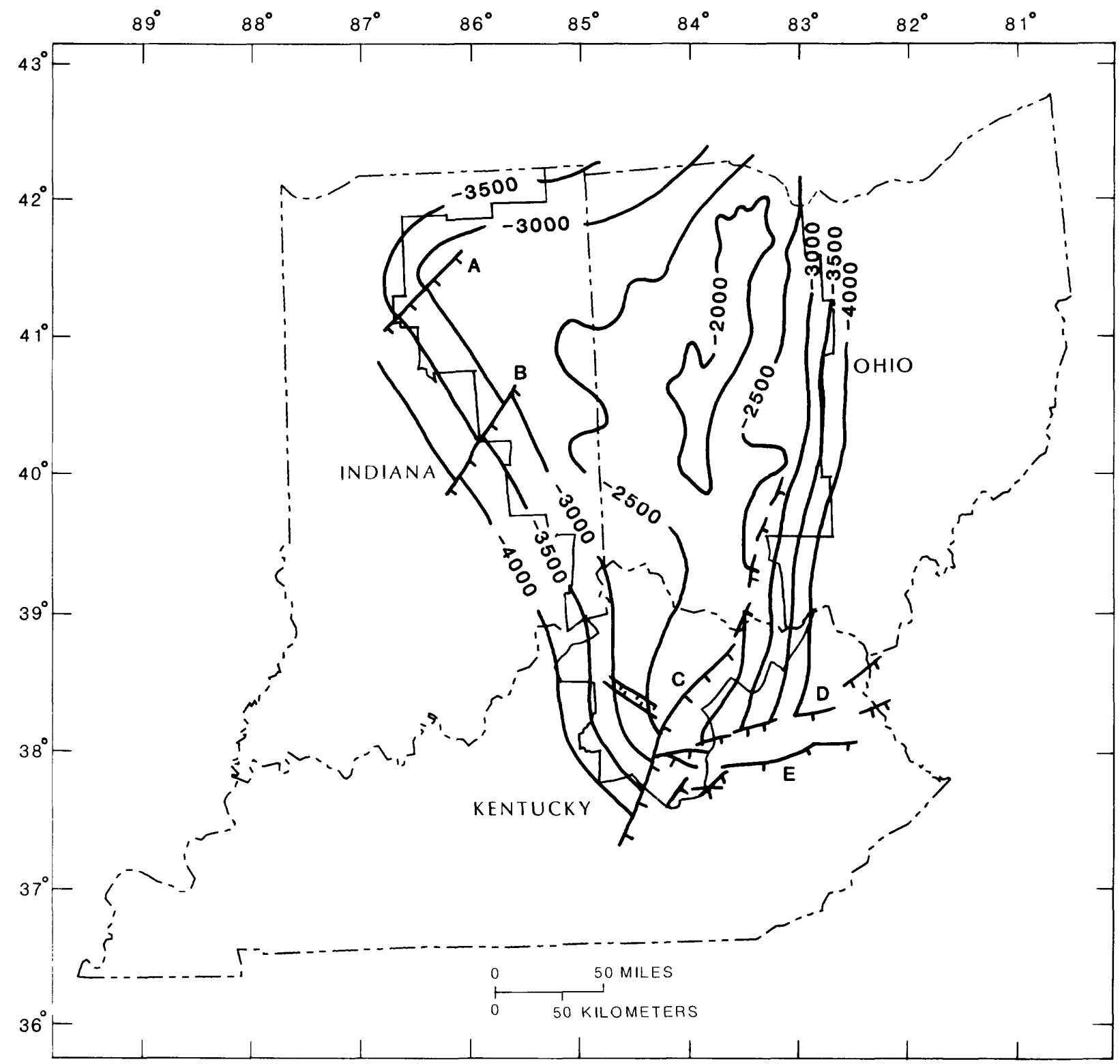

EXPLANATION

- -3500 - STRUCTURE CONTOUR -- Shows altitude of top of crystalline rock. Contour interval is 500 feet. Datum is sea level

TTT $\boldsymbol{T}$ TAULT -- Hachures on apparently downthrown side. A - Royal Center fault, $B$ - Fortville fault, C - Lexington fault system, D - Kentucky River fault system, and $E$ - Irvine-Paint Creek fault system

STUDY AREA BOUNDARY

Figure 3.--Configuration of the top of the crystalline rock in the Cincinnati arch region

(data from Owens, 1967; Harris, 1975; ORSANCO, 1976; Dever and others, 1977; and Becker and others, 1978). 
eastern Kentucky. The crystalline-rock surface averages about 3,500 ft below sea level on the perimeter of the study area.

For mapping convenience, the altitudes of the crystalline-rock surface are referred to sea level rather than the many different land-surface elevations that occur from place to place. The land-surface elevations vary from about 450 and $575 \mathrm{ft}$ above sea level along the Ohio River and the shore of the Great Lakes, respectively, to about 1,500 ft above sea level at the highest interstream divides in west-central and central Ohio. An estimate of depth below land surface to the top of the crystalline rock can be obtained by adding the land-surface elevation (obtained from an appropriate topographic map) to the altitude of the crystalline-rock surface shown on figure 3 for any place or area of interest.

The consolidated and layered sedimentary rocks that overlie the crystalline rock surface are composed primarily of sandstone, siltstone, shale, limestone, and dolomite, and range upward from Cambrian to Mississippian in age (Shaver, 1985). These rocks are draped over a structural high in the crystalline rock surface and form three arches known as the Cincinnati arch, the Findlay arch, and the Kankakee arch (fig. 4).

The oldest rocks exposed at land surface in the area are Ordovician in age and occur in southeastern Indiana, north-central Kentucky, and southwestern Ohio. These Ordovician rocks are rimmed successively by younger rocks that dip away from the axes of the arches (fig. 4). In aggregate, the consolidated sedimentary rocks thicken away from the arches and toward the Illinois basin to the west and southwest, the Michigan basin to the north, and the Appalachian basin to the east and southeast.

Unconsolidated glacial deposits of Quaternary age overlie the consolidated sedimentary rocks north of a line that roughly parallels the Ohio River in the study area (fig. 4). These deposits were derived primarily from erosional and depositional processes associated with glaciation, and they are composed of glacial till, gravel, sand, silt, and clay. The thickness of these deposits may be more than $400 \mathrm{ft}$ in some existing and abandoned buried stream valleys in the northern part of the area. 


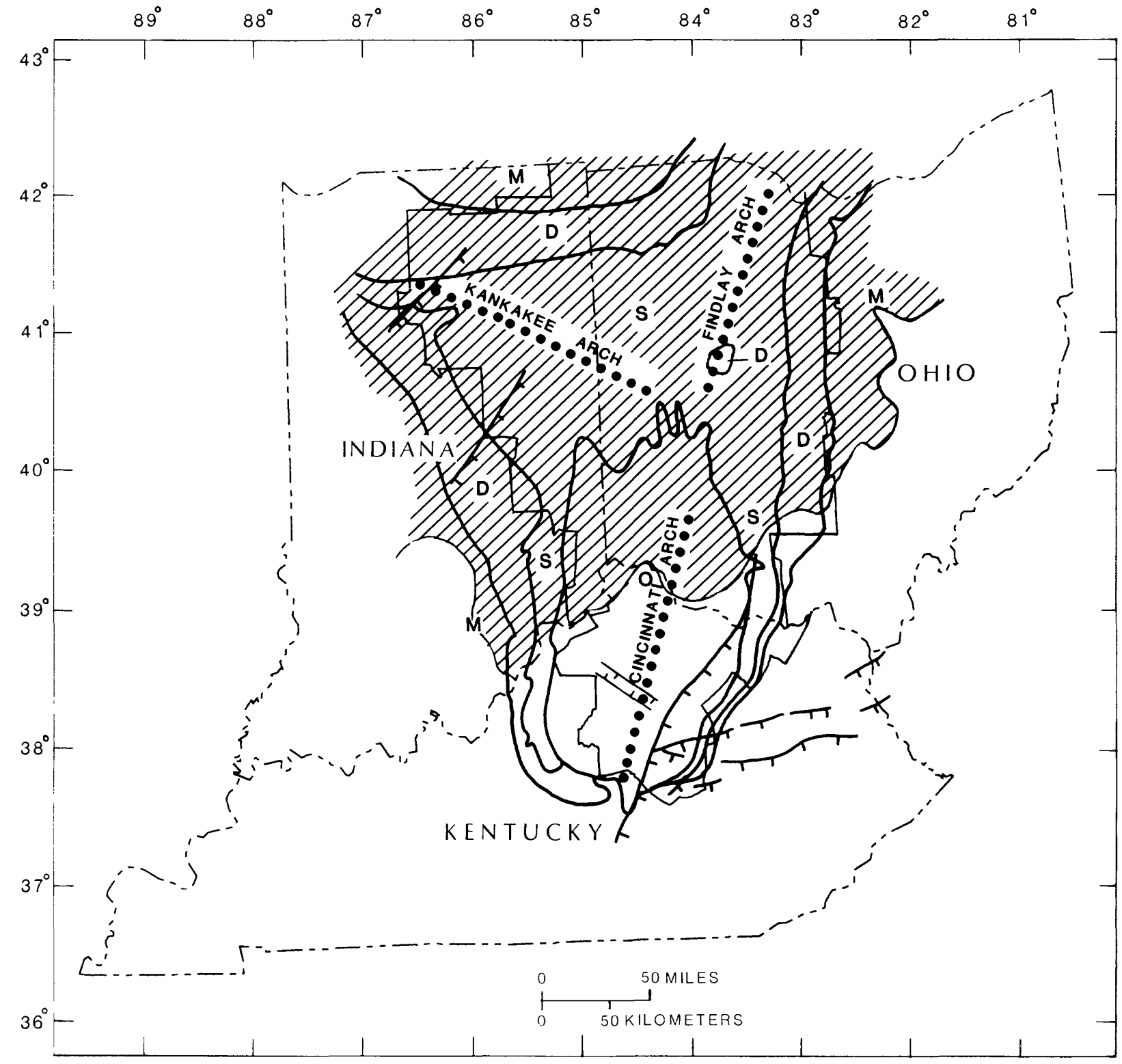

\section{EXPLANATION}

GEOLOGIC ROCK SYSTEMS listed from oldest to youngest :

O - Ordovician, S - Silurian, D - Devonian, M - Mississippian

'LLLL SOUTHERN LIMIT OF GLACIAL DEPOSITS

LINE OF CONTACT BETWEEN ROCK SYSTEMS

TrT T FAULT -- Hachures on apparently downthrown side

$\bullet \bullet \bullet \bullet-$ LINE OF APPROXIMATE LOCATION OF ARCH AXIS

STr STUDY AREA BOUNDARY

Figure 4.--Generalized geology and location of structural arches in in the Cincinnati arch region.

(data from Bownocker, 1947; Indiana Geological Survey, 1970; Bloyd, 1974; and McDowel1 and others, 1981). 
The sedimentary rocks in the area have been divided according to their age and lithology into a number of mappable units. Table 1 shows the general relation between the stratigraphic units in pertinent parts of Indiana, Kentucky, and Ohio, and the dominant rock types that comprise the units.

Both the crystalline rocks and the consolidated sedimentary rocks are broken by high-angle faults that have been mapped in Indiana (Dawson, 1971) and Kentucky (McDowell and others, 1981). Similar faults have been postulated in Ohio (Harris, 1975).

The Royal Center and Fortville faults, located in north-central and central Indiana (fig. 3), have been mapped only from subsurface data because their traces on the consolidated sedimentary-rock surface are obscured by a thick blanket of glacial deposits (Dawson, 1971). These faults are estimated to be between 45 and $55 \mathrm{mi}$ long. The maximum vertical displacement along these faults is estimated to range between 50 and $100 \mathrm{ft}$.

The Lexington, Kentucky River, and Irvine-Paint Creek fault systems, mapped in central and eastern Kentucky (McDowell and others, 1981) (fig. 3), are northeast- and east-northeast-striking high-angle faults that bound a series of grabens, half grabens, and horsts. Each of these fault systems can be traced at land surface for a distance of between 100 and $125 \mathrm{mi}$. As much as $250 \mathrm{ft}$ of vertical displacement is estimated along some of these faults at land surface (McDowell and others, 1981). However, much more vertical movement can be inferred in the subsurface along the Kentucky River fault because of the abrupt and large amount of thickening of the Rome Formation south of the fault. An extension of the Lexington fault system has been projected in the subsurface as far north as Pickaway County, Ohio (Harris, 1975).

The general subsurface distribution of the crystalline- and sedimentary-rock systems and the nature of some of the faults that cut across the rocks are shown in the hydrogeologic sections in plates 1 and 2 (back pocket). The locations of these sections are shown in figure 2 . 
Table 1.--Generalized correlation chart for rocks underlying parts of the Cincinnati arch region

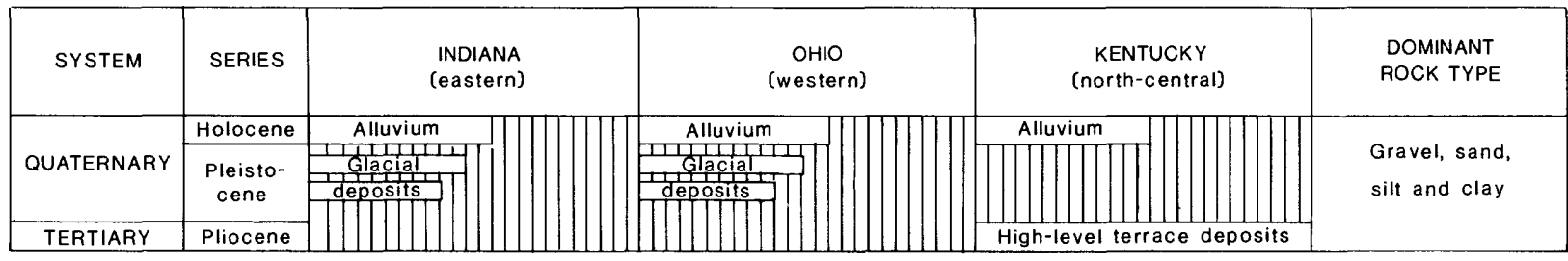

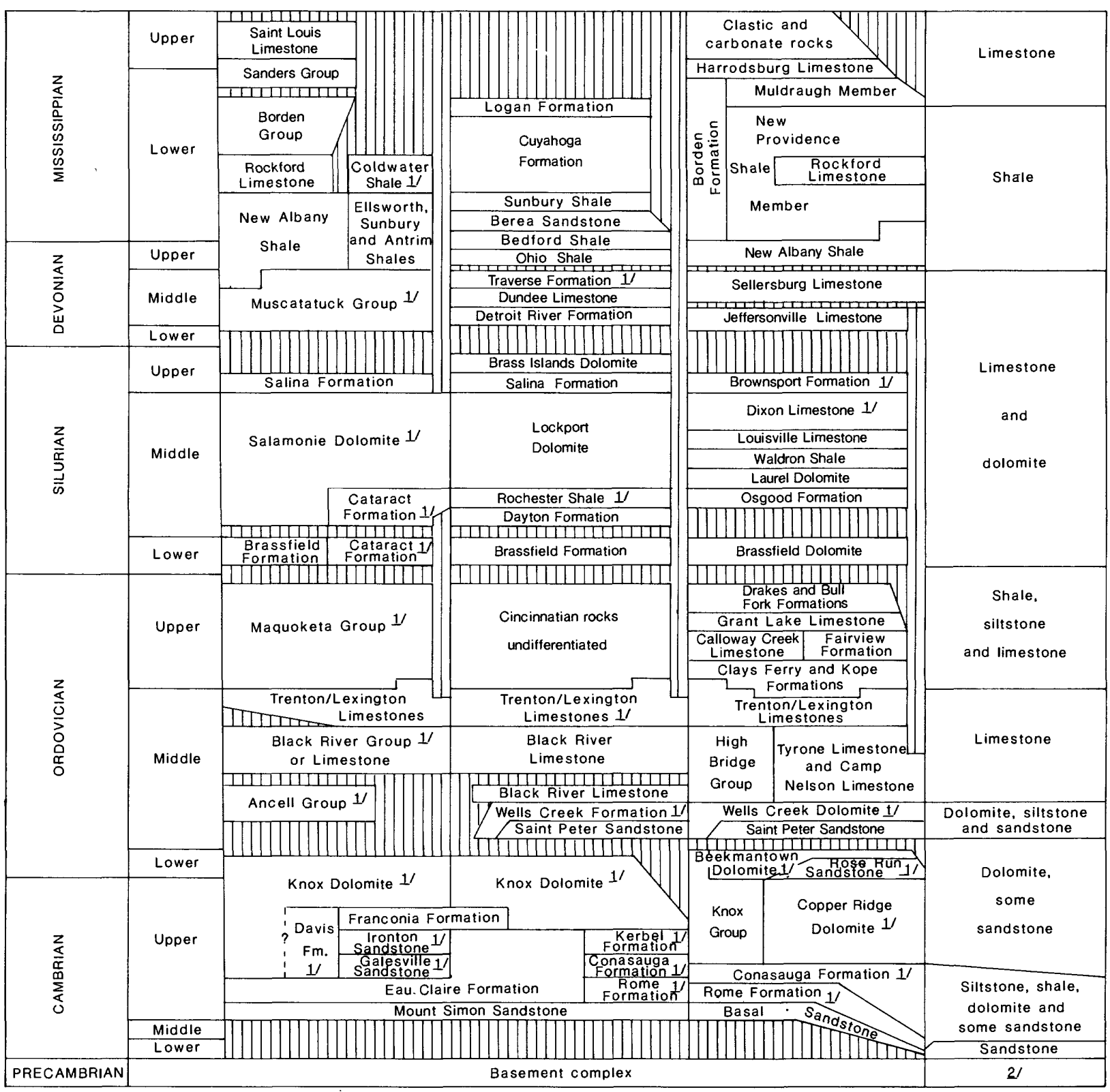

1 Names from Correlation of stratigraphic units of North America (COSUNA) project (see Shaver, 1985). Nomenclature may not agree with U.S. Geological Survey usage.

2/ Basement complex composed primarily of granite, rhyolite, basalt, gneiss, schist, and amphibolite 


\section{Hydrogeologic Framework}

The sedimentary rocks that underlie the study area can be divided into hydrogeologic units--aquifer and confining units--that constitute the hydrogeologic framework which controls ground-water occurrence and movement. An aquifer is a formation, group of formations, or parts of formations that contain a preponderance of saturated permeable material (generally sandstone, limestone, and dolomite in the study area) that will yield significant quantities of water to wells. An aquifer may be composed of interconnected saturated permeable material of different ages. In general, aquifers are stratigraphically adjacent to confining units that are composed mostly of saturated material with low permeability (silt, clay, siltstone, shale, and in some cases massive limestone and dolomite in the study area). A confining unit, like an aquifer, may be composed of materials of different ages.

The hydrogeologic units of greatest importance to this study are the lowermost ones which are referred to here as the basal sandstone aquifer and the potential confining unit. Figure 5 shows a diagrammatic relationship between the stratigraphic units and the rock types that comprise the lowermost hydrogeologic units.

\section{Basal Sandstone Aquifer}

The basal sandstone aquifer is primarily composed of Cambrian sedimentary rocks known formally as the Mount Simon Sandstone in Indiana and Ohio, and informally as the basal sand in Kentucky (table 1). In addition, glauconitic sandstone that occurs in the lower parts of the Eau Claire and Rome Formations, and that directly overlies the Mount Simon, is included as part of the basal sandstone aquifer. Generally, the basal sandstone aquifer is poorly sorted, poorly consolidated, fine-grained to conglomeratic, may be arkosic (contain feldspar) at the base of the section, and is commonly interlayered with thin beds of siltstone, shale, and some dolomite. The thickness of the basal sandstone aquifer ranges from about 1,000 ft in the westernmost part of the area in north-central Indiana to less than $100 \mathrm{ft}$ near the eastern boundary of the study area in central Ohio (ORSANCO, 1976; and Janssens, 1973). 


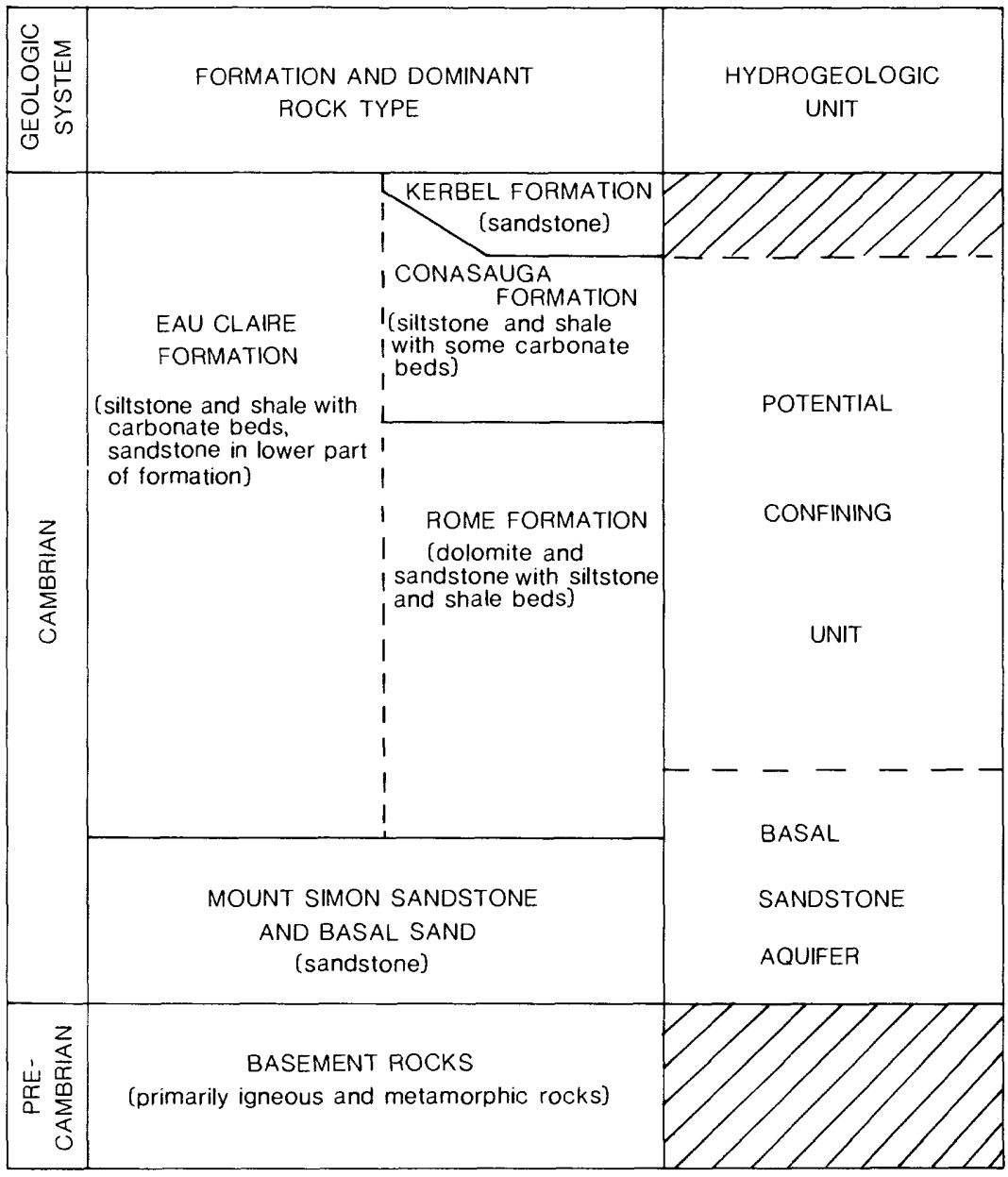

Figure 5.--Relation between stratigraphic units, the basal sandstone aquifer, and the potential confining unit.

Published porosity data (Janssens, 1973, appendix C; ORSANCO, 1974; ORSANCO, 1976, tables 2, 3, and 5; Becker and others, 1978, appendix 2, table 3) for sandstones that comprise the basal sandstone aquifer indicate that the porosity ranges from 2 to 24 percent and averages about 13 percent. Figure 6 shows the distribution of the average porosity in the basal sandstone aquifer. The porosity data are derived from about 70 wells with broad geographic distribution (ORSANCO, 1976, tables 2, 3, and 5). The average porosity values were determined from core analyses and geophysical $10 \mathrm{~g}$ examination for each well as reported by ORSANCO (1976, p. 9). The porosity values are less than 10 percent generally on the northern, western, and southern boundaries of the area, and greater than 20 percent in isolated areas in the north-central and eastern parts. 


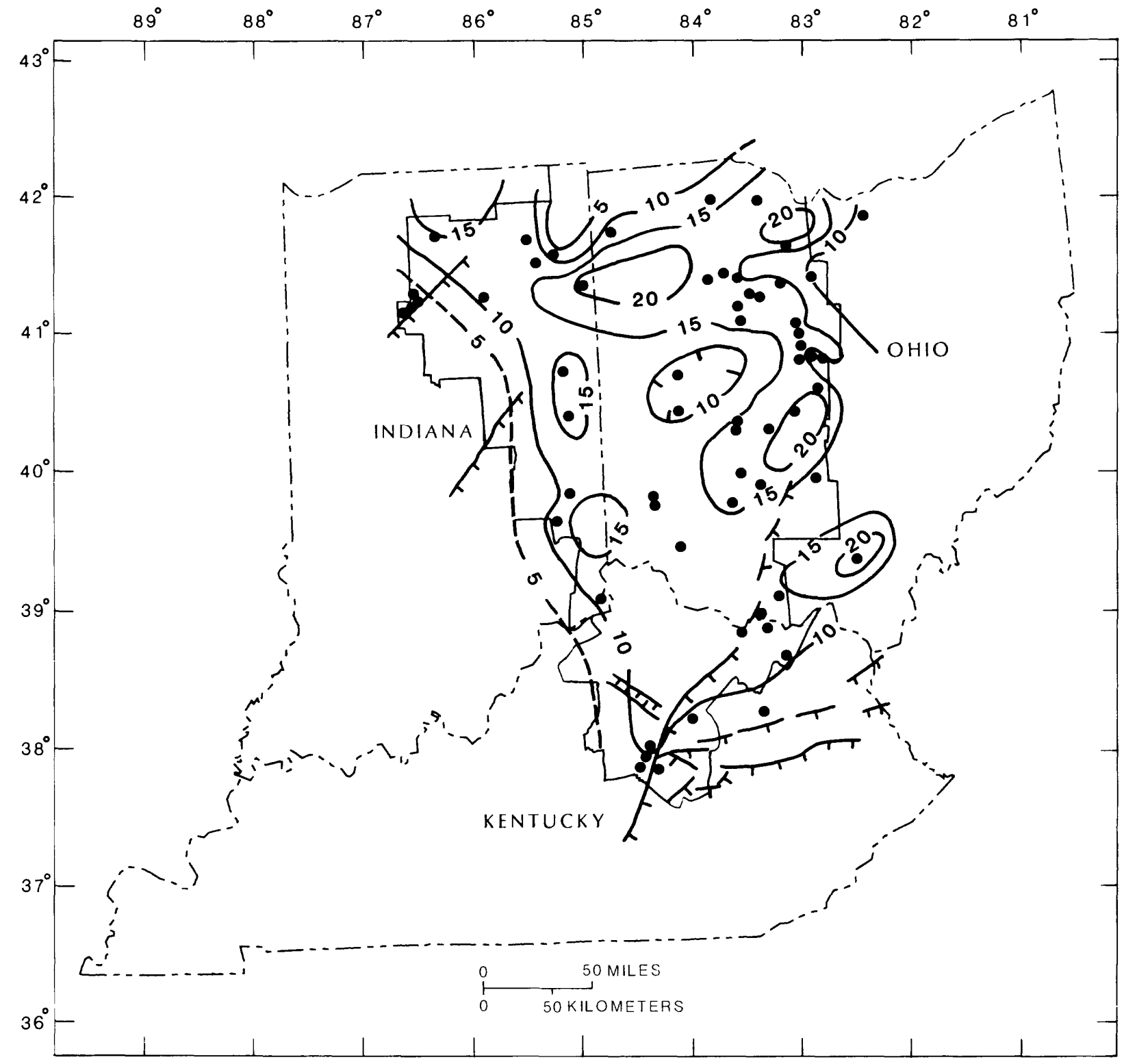

\section{EXPLANATION}

-10- - LINE OF EQUAL AVERAGE POROSITY -- Interval 5 percent. Dashed where approximately located

TT T T F T - Hachures on apparently downthrown side.

- DATA POINT

בשת STUDY AREA BOUNDARY

Figure 6.--Average porosity of the basal sandstone aquifer in the Cincinnati arch region (data from ORSANCO, 1976, (tables 2, 3, and 5)). 
Published permeability data (Janssens, 1973, appendix C; ORSANCO, 1974; ORSANCO, 1976, tables 2, 3, and 5; Becker and others, 1978, appendix 2, table 3) are available for a few wells finished in the sandstones that comprise the basal sandstone aquifer. These data indicate that horizontal permeability ranges from less than 1 md (millidarcy) to 1,850 md and averages about $30 \mathrm{md}$. The permeability data were derived mainly from laboratory analyses on core samples from the Mount Simon Sandstone. The data are far too few to map the permeability distribution in the basal sandstone aquifer.

A total of 157 laboratory analyses of samples of Mount Simon Sandstone from three wells in Indiana (NIPSCO No. 1 Leuenberger in Allen County (well IN-13 in table 3, this report); Inland Steel No. WD-1 in Lake County; and Midwest No. WD-I in Porter County) show horizontal to vertical permeability ratios that range from less than 1:1 to 1,200:1 with a mean value of 25:1 and a median of 4:1 (Becker and others, 1978). Both Lake and Porter Counties are located west of the study area, and the permeability ratios given here are useable only as general indicators until more data within the study area become available.

\section{Potential Confining Unit}

The interval between the top of the basal sandstone aquifer and the top of the Eau Claire, Conasauga, and Rome Formations is composed mainly of shale, siltstone, dolomite, and limestone with small amounts of sandstone. This interval is referred to as the potential confining unit in this report (fig. 5). Because it is difficult to predict whether the dolomite or limestone will function as an aquifer or confining unit, only the shale and siltstone that occur within the unit are mapped as confining material. Further, only the thickest consecutive unit of siltstone and (or) shale, determined from an examination of geophysical logs, is mapped in figure 7. The clay particles that constitute the shale are also found in various concentrations throughout the siltstones; they impede vertical ground-water flow and tend to sorb and impede the movement of some contaminants in the water.

Geophysical- and 1ithologic-log data indicate that the thickest consecutive beds of siltstone and (or) shale in the potential confining unit are over 500 feet thick in the western part of the study area in Indiana, 


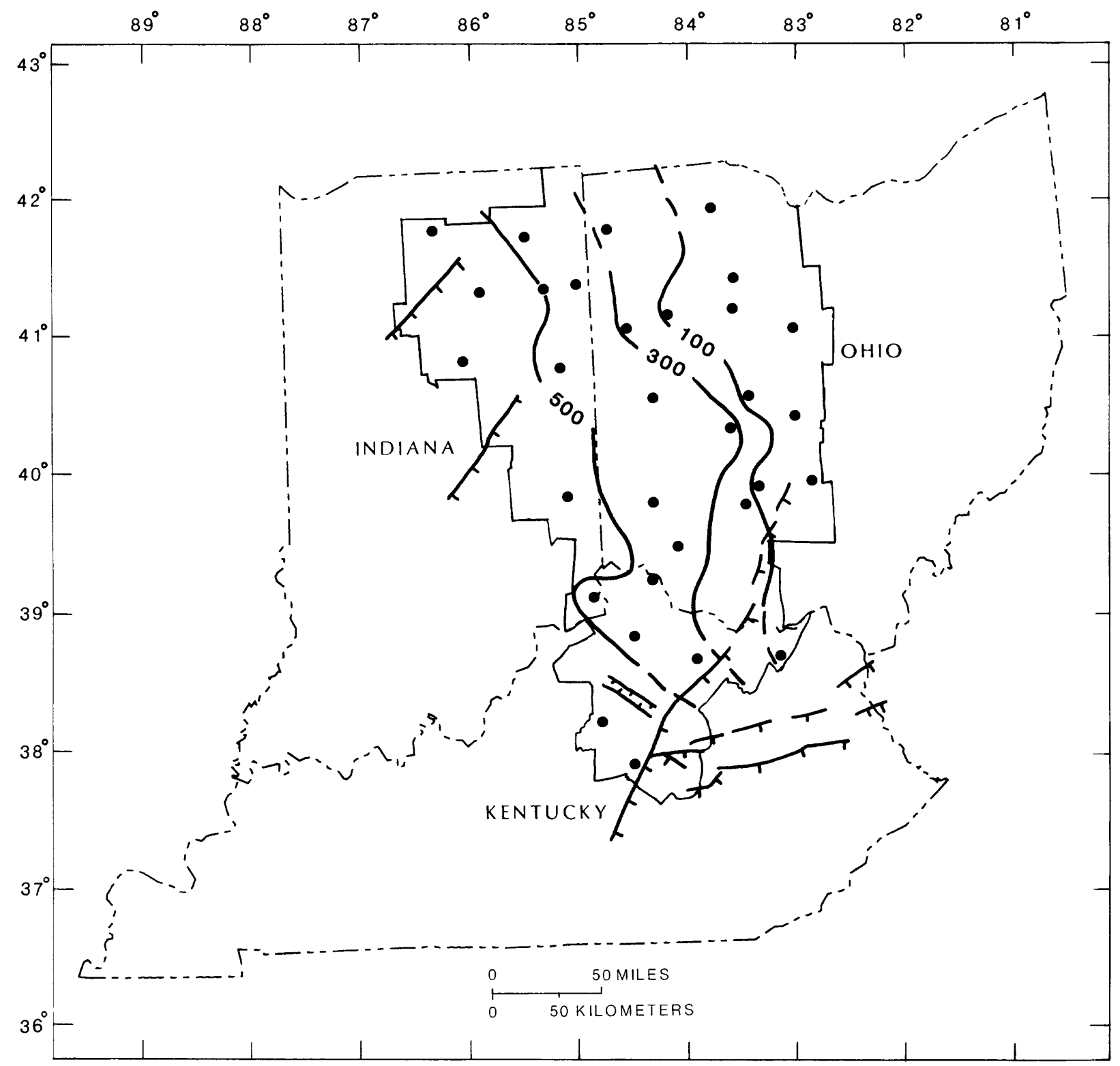

EXPLANATION

-500-- LINE OF EQUAL THICKNESS OF SHALE AND SILTSTONE -- Dashed where approximately located. Interval 200 feet T T T T T T -- Hachures on apparently downthrown side. Dashed where
approximately located

- DATA POINT

STUDY AREA BOUNDARY

Figure 7.--Estimated distribution of thickest consecutive shale and siltstone beds in the potential confining unit in the Cincinnati arch region

(data from interpretation of geophysical and lithologic logs and from Janssens, 1973; ORSANCO, 1976; and Becker and others, 1978). 
Kentucky, and Ohio (fig. 7). Toward the east, in Ohio and in Kentucky north of the Kentucky River fault system, the major parts of the shale and siltstone thin or grade into the dolomites, limestones, and sandstones that comprise the Rome, Conasauga, and Kerbel Formations (Janssens, 1973, p. 2, 11). Thus, the greatest consecutive thickness of shale and (or) siltstone within the potential confining interval in the easternmost parts of the area is less than $100 \mathrm{ft}$ (fig. 7). Crystalline rock is too deep south of the Kentucky River fault system to be considered feasible for the application of the buried crystalline-rock concept under the present criteria. Table 2 lists the estimated greatest consecutive thickness of shale and siltstone in the potential confining unit for selected wells in the study area.

A total of 184 laboratory analyses of shale-siltstone samples taken from the Eau Claire Formation in two wells in Allen County, Indiana (Becker and others, 1978, p. 53-61), indicate vertical permeability values that range from about $1 \times 10^{-6}$ to $1 \times 10^{-1} \mathrm{md}$ and average about $1 \times 10^{-4} \mathrm{md}$. These average vertical permeability values are four orders of magnitude less than those reported for the Mount Simon Sandstone.

The general distribution of the basal sandstone aquifer and the potential confining unit within the sedimentary-rock section is shown in plates 1 and 2 (back pocket). Plate 1 displays the relation between the hydrologic units in a general east-west direction, and plate 2 shows the relation in a north-south direction.

\section{Distribution and Source of Freshwater, Saline Water, and Brine}

The sedimentary rocks that underlie the study area are saturated with freshwater in the upper part of the section and with saline water and brine in the middle and lower parts. Freshwater contains less than $1,000 \mathrm{mg} / \mathrm{L}$ dissolved solids, saline water contains between 1,000 and $35,000 \mathrm{mg} / \mathrm{L}$, and brine contains more than $35,000 \mathrm{mg} / \mathrm{L}$ dissolved solids (Hem, 1970, p. 219). For comparison purposes, dissolved-solids concentrations in seawater are about $35,000 \mathrm{mg} / \mathrm{L}$ (Hem, 1970, p. 11).

In general, the freshwater in the area occurs at depths of less than $500 \mathrm{ft}$ below land surface (Feth and others, 1965; Bloyd, 1974). At any given location, dissolved-solids concentrations in the ground water 
Table 2.--Greatest consecutive thickness of shale and (or) siltstone in the potential confining unit

\begin{tabular}{|c|c|c|c|}
\hline $\begin{array}{c}\text { We11 } \\
\text { number }\end{array}$ & $\begin{array}{l}\text { Log depth } \\
\text { to top } \\
\text { (feet) }\end{array}$ & $\begin{array}{c}\text { Log depth } \\
\text { to base } \\
\text { (feet) }\end{array}$ & $\begin{array}{c}\text { Thickness } \\
\text { (feet) }\end{array}$ \\
\hline $\begin{array}{r}\text { IN-2 } \\
\text { IN-3 } \\
\text { IN }-11 \\
\text { IN-12 } \\
\text { IN-13 } \\
\text { IN } 134 \\
\text { IN }-17 \\
\text { IN }-19 \\
\text { IN-23 } \\
\text { IN-26 }\end{array}$ & $\begin{array}{l}2,458 \\
3,090 \\
2,458 \\
2,420 \\
2,670 \\
2,345 \\
2,480 \\
2,725 \\
2,880 \\
3,155\end{array}$ & $\begin{array}{l}3,004 \\
3,575 \\
2,994 \\
2,920 \\
3,120 \\
2,855 \\
2,920 \\
3,265 \\
3,412 \\
3,625\end{array}$ & $\begin{array}{l}546 \\
485 \\
536 \\
500 \\
450 \\
510 \\
440 \\
540 \\
532 \\
470\end{array}$ \\
\hline $\begin{array}{l}\mathrm{KY}-1 \\
\mathrm{KY}-2 \\
\mathrm{KY}-3 \\
\mathrm{KY}-4 \\
\mathrm{KY}-5 \\
\mathrm{KY}-6 \\
\mathrm{KY}-12\end{array}$ & $\begin{array}{l}2,870 \\
2,670 \\
2,915 \\
2,445 \\
2,780 \\
4,110 \\
3,830\end{array}$ & $\begin{array}{l}3,410 \\
3,050 \\
3,390 \\
2,840 \\
2,920 \\
4,175 \\
4,545\end{array}$ & $\begin{array}{r}540 \\
380 \\
475 \\
395 \\
140 \\
65 \\
715\end{array}$ \\
\hline $\begin{array}{l}\mathrm{OH}-4 \\
\mathrm{OH}-6 \\
\mathrm{OH}-15 \\
\mathrm{OH}-21 \\
\mathrm{OH}-23 \\
\mathrm{OH}-24 \\
\mathrm{OH}-25 \\
\mathrm{OH}-29 \\
\mathrm{OH}-30 \\
\mathrm{OH}-34 \\
\mathrm{OH}-35 \\
\mathrm{OH}-38 \\
\mathrm{OH}-40 \\
\mathrm{OH}-41 \\
\mathrm{OH}-44 \\
\mathrm{OH}-45 \\
\mathrm{OH}-48\end{array}$ & $\begin{array}{l}3,130 \\
2,220 \\
2,220 \\
3,220 \\
2,420 \\
2,490 \\
2,460 \\
2,504 \\
2,620 \\
2,995 \\
2,707 \\
2,810 \\
2,425 \\
2,585 \\
2,805 \\
2,840 \\
3,480\end{array}$ & $\begin{array}{l}3,380 \\
2,265 \\
2,275 \\
3,250 \\
2,490 \\
2,590 \\
2,750 \\
2,890 \\
2,730 \\
3,040 \\
2,770 \\
3,180 \\
2,840 \\
2,995 \\
2,930 \\
2,920 \\
3,530\end{array}$ & $\begin{array}{r}250 \\
45 \\
55 \\
30 \\
70 \\
100 \\
290 \\
386 \\
110 \\
45 \\
63 \\
370 \\
415 \\
410 \\
125 \\
80 \\
50\end{array}$ \\
\hline
\end{tabular}

1/A11 data from ORSANCO, 1976. 
generally increase with depth through the sedimentary section and reach a maximum concentration in the basal sandstone aquifer.

Available water-quality data for the basal sandstone aquifer in the study area (ORSANCO, 1976, tables 9, 10, and 11) indicate that dissolvedsolids concentrations in the top part of the aquifer range from less than $25,000 \mathrm{mg} / \mathrm{L}$ to more than $250,000 \mathrm{mg} / \mathrm{L}$ (fig. 8). These data are mostly from calculations made from geophysical logs. The water that contains the lowest dissolved solids in the basal aquifer occurs on the northern flank of the Kankakee arch and on the Cincinnati arch in the vicinity of the Ohio River. In general, the dissolved solids increase downdip toward the west, southwest, east and southeast. The water with the highest dissolved-solids concentrations in the top part of the basal sandstone aquifer occurs in southeastern Indiana and adjacent parts of Ohio, and in southern ohio and adjacent parts of northeastern Kentucky (fig. 8).

The source of the freshwater in the sedimentary rocks is precipitation. The source of the saline water is presumed to be some combination of the fresh ground water and the seawater in which the sediments were deposited or by which they were later invaded. The origin of the brine is problematical, but it may be derived from a number of processes among which are included ionic filtration by shales as formation water circulated through the rocks over long periods of geologic time (Bredehoeft and others, 1963), chemical reactions with the rocks through which the water circulated (Heck and others, 1964), dissolution of evaporite deposits, and entrapment of brines produced by evaporation of seawater before or during the deposition of the rocks.

Heck and others (1964) indicate that dissolved solids in a representative sample of most of the brines found in West Virginia and Ohio are composed of about 60 to 65 percent chloride, 20 to 25 percent sodium, and 10 to 15 percent calcium. Keller (1983) reports similar composition for brines in Indiana.

\section{Ground-Water Occurrence and Movement}

Part of the precipitation that falls on the study area infiltrates the land surface, reaches the water table, which is the upper surface of the saturated zone, and enters the ground-water system. "Water enters ground- 


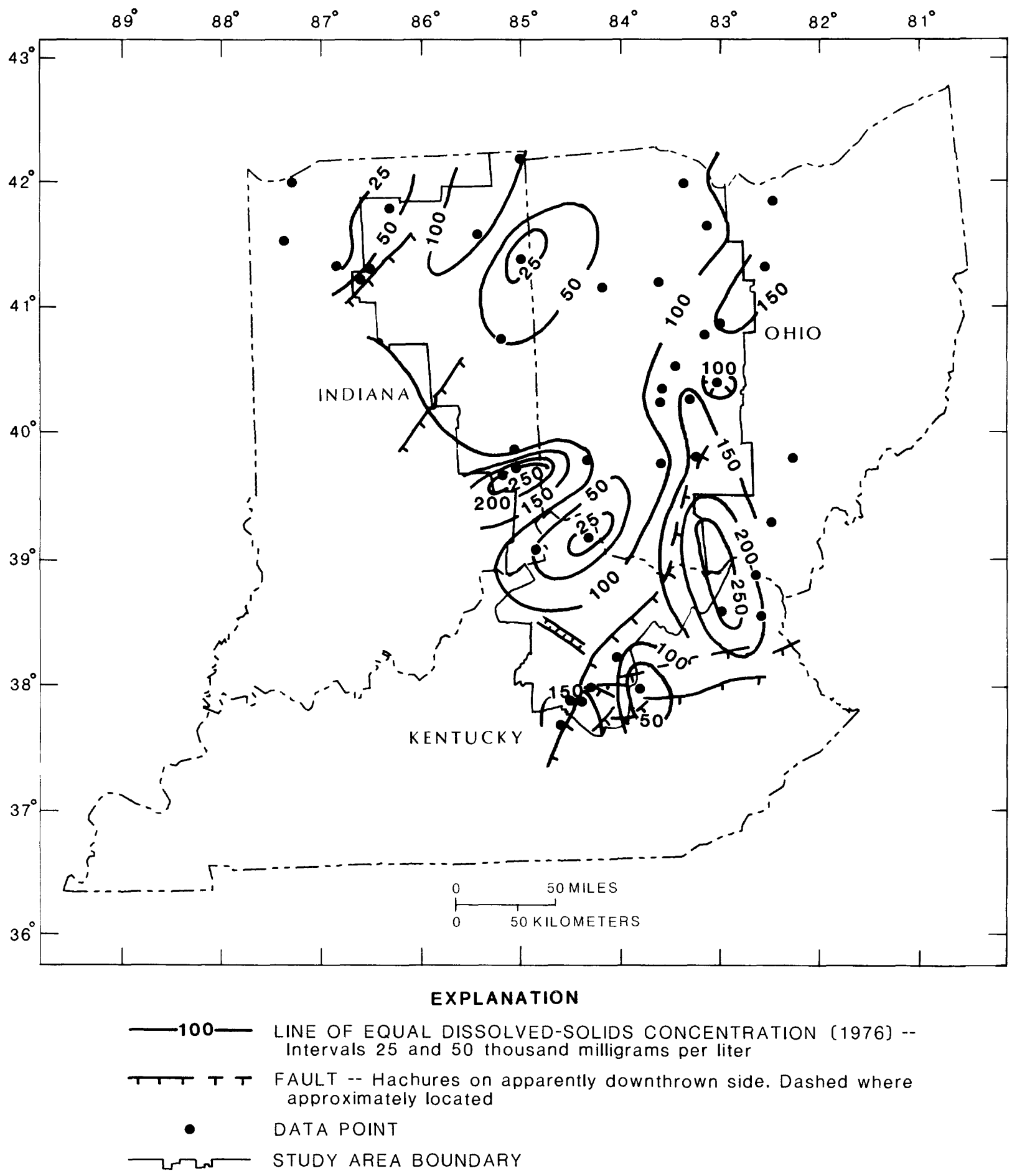

Figure 8.--Dissolved-solids concentration in the top part of the basal sandstone aquifer in the Cincinnati arch region (data from ORSANCO, 1976 (tables 9, 10, and 11)). 
water systems in recharge areas and moves through them, as dictated by hydraulic gradients and hydraulic conductivities, to discharge areas. ...In the humid part of the country, recharge occurs in all interstream areas-that is, in all areas except along streams and their adjoining flood plains. The stream's and flood plains are, under most conditions, discharge areas." (Heath, 1983, p. 14.)

Only a small percentage of precipitation in the area reaches the ground-water system. Long-term average annual precipitation ranges from about $48 \mathrm{in.}$ at the southern tip of the area to less than $32 \mathrm{in.}$ at the northeastern boundary and has a mean of about 38 in. (U.S. Geological Survey, 1970). Of this precipitation, it is estimated that, on the average, about 4 to $6 \mathrm{in}$. percolates to the water table (the top of the zone of saturation) and enters the ground-water system (U.S. Geological Survey, 1984, p. 205, 223, and 341).

The ground water in the zone of saturation occurs in and moves through intergrannular pore spaces in the unconsolidated surficial deposits and in some of the underlying consolidated rocks like the Mount Simon Sandstone, some of the oolitic parts of the Knox Dolomite (and equivalents), and sandstone in the Eau Claire Formation and in the Rome Formation. Within the consolidated rocks, ground water also occurs in and moves through fractures, some of which may be enlarged by solution particularly in the limestones and dolomites.

It is believed that small fractures occur across confining units like shale as this material is compacted and consolidated, and that these small fractures provide some of the pathways along which a very slow migration of ground water occurs (Neglia, 1979). As an example, Bredehoeft and others (1983) and Neuzil and others (1982) report evidence that suggests much of the ground-water leakage across Cretaceous-aged shales overlying the Dakota Sandstone occurs as flow through fractures. Such flow through fractures is entirely possible across the shales and siltstones that confine the basal sandstone aquifer in the Cincinnati arch region.

The ground water moves through the system in response to gravity, from areas where hydraulic heads (water levels) are high (recharge areas) to areas where heads are low (discharge areas). Hydraulic heads are higher in interstream upland areas than they are adjacent to nearby streams. Thus, 
the ground water flows away from the uplands and discharges in the streams and lakes. Figure 9 shows the distribution of the major uplands, streams, and lakes in the area.

Ground water also moves toward lowered water levels (heads) caused by pumping wells. However, large ground-water withdrawals in the study area are from wells that tap unconsolidated and consolidated rock aquifers at depths that are generally less than $500 \mathrm{ft}$ below land surface (U.S. Geological Survey, 1984). Because of the relatively shallow depth of these wells and the presence of shale and siltstone confining beds in the underlying consolidated sedimentary rocks, particularly those in the upper part of the Ordovician units and those in the Cambrian rocks, it is reasonable to assume that ground-water withdrawals in the area have very little or no significant effect on ground-water movement in the basal sandstone aquifer.

Because saline water generally occurs below about $500 \mathrm{ft}$ below land surface (Feth and others, 1965; Bloyd, 1974), it is assumed that most of the ground water moves through the system at depths of less than $500 \mathrm{ft}$ below land surface. In the northern part of the area, most of this movement occurs in the unconsolidated glacial deposits that blanket the Paleozoic sedimentary rocks (fig. 4). South of the glacial deposits most of the movement occurs in the shallow weathered and unweathered parts of the Paleozoic rocks. A small part of ground-water recharge is believed to circulate deeper than $500 \mathrm{ft}$ below land surface.

Hydraulic-head data are considered to be insufficient to determine the direction and rate of ground-water movement in the saline-water and brinebearing parts of the sedimentary section in the study area. "The [available] hydraulic-head data for the Mount Simon...are sparse, of questionable accuracy, too widely spaced to be used to determine groundwater gradients, and give practically no information about hydraulic boundaries," (A.M. La Sala, Jr., U.S. Geological Survey, Columbus, Ohio, written commun., 1986). The available head data for the Mount Simon Sandstone in and near the study area primarily are from 10 wells drilled in parts of Indiana, Kentucky, Michigan, and Ohio (Clifford, 1973, p. 353).

The more abundant water-quality data for the Mount Simon Sandstone and the basal sandstone aquifer may be used to help outline gross patterns of 


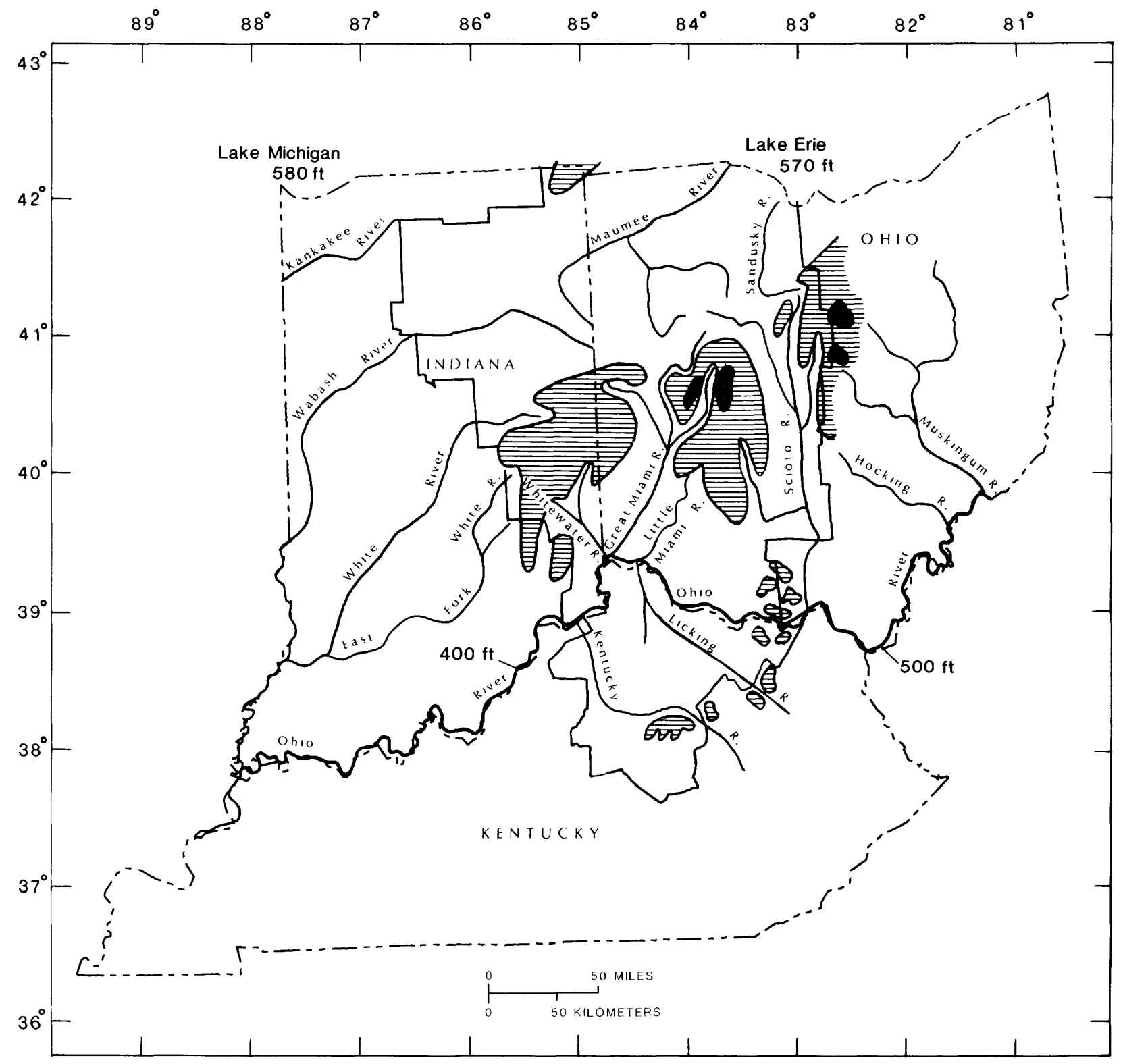

EXPLANATION

LAND SURFACE ALTITUDE, IN FEET ABOVE SEA LEVEL

$\square$ Less than 1,000

1,000 to 1,300

1,301 to 1,500

$580 \mathbf{f t}$ APPROXIMATE WATER-SURFACE ALTITUDE ABOVE SEA LEVEL

Un STUDY AREA BOUNDARY

Figure 9.--Land-surface altitude and streams and lakes in the Cincinnati arch region. 
deep ground-water circulation. In general, the least saline water in the top part of the basal sandstone aquifer occurs in the heart of the study area near the crests of the arches. Figure 8 indicates that water with dissolved-solids concentrations of less than $100,000 \mathrm{mg} / \mathrm{L}$ is found in the basal aquifer throughout most of the study area. The occurrence of water with dissolved-solids concentrations lower than seawater (less than about $35,000 \mathrm{mg} / \mathrm{L}$ ) suggests that freshwater has entered the aquifer in or near the arches and has partly flushed the saline water from the sandstone (A.M. La Sala, Jr., U.S. Geological Survey, Columbus, Ohio, written commun., 1986).

At present it appears that only a limited relation exists between the general distribution of the dissolved solids in water contained by the basal sandstone aquifer and the areas that would be expected to be the major present-day recharge and discharge areas for deep regional ground-water circulation (the major uplands and major rivers and lakes). For example, the least saline water is not found beneath west-central Ohio and eastcentral Indiana where land-surface elevations and water-table altitudes are the highest in the area and where the largest hydraulic gradients probably occur for deep ground-water circulation. The most apparent incongruous relationship in this regard is found in northernmost Kentucky and adjacent parts of Indiana and Ohio. Here the least saline water in the basal sandstone aquifer occurs beneath the Ohio River, which would usually be interpreted as a line of major regional discharge. The best relation is found near the intersection of $41^{\circ} \mathrm{N}$ latitude and the Indiana-Ohio State line, where the least saline water in the basal sandstone aquifer occurs beneath the present surface divide between the Ohio River and the Great Lakes drainage basins (compare figs. 8 and 9).

The apparent lack of a strong direct relation between the distribution of dissolved-solids concentrations in the basal sandstone aquifer and the present-day regional recharge and discharge areas is caused by one or some combination of the following factors:

1. The water-quality data for the basal sandstone aquifer may be too widely scattered to make a definitive map of dissolved-solids distribution. 
2. Fresh ground water may be moving downward where the geologic conditions are most favorable (such as in the faulted areas), and then laterally and, finally, downward into the basal sandstone aquifer in the area where it contains less saline water.

3. The dissolved-solids concentrations in the basal sandstone aquifer may be, in large part, residual from past geologic times (Pleistocene and older) when recharge and discharge areas may have been located significantly different than at present.

4. The dissolved-solids concentrations in the basal sandstone aquifer may reflect ground-water movement along some as yet unknown superregional flow system.

A more detailed study is needed to evaluate the importance of each of these factors. Nevertheless, it is estimated that high concentrations of dissolved solids in water in the basal sandstone aquifer can be used as a preliminary indication of areas where ground-water circulation is restricted.

\section{RELATIVE HYDROGEOLOGIC SUITABILITY OF SEDIMENTARY ROCKS FOR HIGH-LEVEL RADIOACTIVE WASTE DISPOSAL IN BURIED CRYSTALLINE ROCK}

The five general characteristics used to make a preliminary evaluation of the hydrogeologic suitability for disposal of high-level radioactive waste in crystalline rocks that underlie the area are discussed in the following sections.

\section{Depth to Crystalline Rock}

One of the major criteria for determining areas that might be suitable for the application of the buried crystalline-rock concept is that the top of the crystalline rock lies between $1,000 \mathrm{ft}$ and 4,000 ft below land surface. Within these depth constraints, and assuming all other factors remain the same, it follows that the deeper the top of the crystalline rock, the thicker the sedimentary-rock cover and the better the chance for longterm isolation of any crystalline-rock repository from the freshwatercirculation system and the biosphere. 
The deepest occurrence of the top of crystalline rock within the depth constraints, allowing for the general altitude of land surface, is found on the periphery of the study area and is approximately outlined between the minus 2,500-ft and minus 3,500-ft altitude lines on figure 3 . The largest areas of deepest occurrence are found in the western part of the study area in eastern Indiana, north-central Kentucky, and in the southwestern and northwestern parts of Ohio. These areas are considered to be the most favorable in the study area for the application of the buried crystallinerock concept regarding this criteria.

\section{Dissolved-Solids Distribution in the Basal Sandstone Aquifer}

The dissolved-solids concentration in water in the upper part of the basal sandstone aquifer ranges from less than $25,000 \mathrm{mg} / \mathrm{L}$ to more than $250,000 \mathrm{mg} / \mathrm{L}$ ( $\mathrm{fig} .8$ ). The concentration of the dissolved solids is assumed to have a direct relationship with the lack of circulation of the water in the aquifer. In other words, the higher the dissolved-solids concentration, the less mobile the water and the better the conditions for the isolation of any potential disposal site in the buried crystalline rock from the freshwater-circulation system.

In general, figure 8 indicates that water with dissolved-solids concentrations of $100,000 \mathrm{mg} / \mathrm{L}$ or more is found in the southwestern, southern, and eastern parts of the study area. Concentrations exceed $250,000 \mathrm{mg} / \mathrm{L}$ in two places--in the southeast around the Kentucky-Ohio state line, and in the southeastern part of Indiana. The areas where dissolvedsolids concentrations are $100,000 \mathrm{mg} / \mathrm{L}$ or more are considered to be the most favorable in the study area for the application of this characteristic to the buried crystalline-rock concept.

\section{Porosity Distribution in the Basal Sandstone Aquifer}

Owing to the lack of definitive hydraulic-head and hydraulicconductivity data, porosity distribution is used as an indicator of the potential for ground-water flow and contaminant migration in the basal sandstone aquifer. Ground-water flow would be one of the major vehicles for the migration of any radionuclides that might find their way into the basal sandstone aquifer from any disposal repository in the underlying crystalline rocks. 
Published porosity data and a limited amount of published permeability data (Janssens, 1973; ORSANCO, 1974; Becker and others, 1978) for the Mount Simon sandstone indicate that an arithmetic decrease in porosity will be accompanied, in general, by a logarithmic decrease in permeability of the basal sandstone aquifer. A relation between porosity and the 1 og of permeability has been well documented for sandstones by Levorsen (1958, p. 128-130) and Pettijohn (1975, p. 76-79), among others.

Thus, it is assumed that the parts of the basal sandstone aquifer that have low porosity also will have low permeability. Therefore, if all other factors remain constant, the volume of water that flows through these parts of the aquifer will be smaller and, possibly, will move at lower velocity than that which flows through parts with higher porosity and permeability. Under this assumption, those parts of the basal sandstone aquifer that have low porosity will have the lowest potential for contaminant migration.

Figure 6 shows the distribution of the average porosity in the basal sandstone aquifer and indicates that relatively low porosity (less than 10 percent) occurs mainly on the southern, western, and northern boundaries of the study area. Also, two small areas of relatively low porosity occur in north-central and west-central ohio. All these areas of low porosity are considered to be the most favorable in the study area for the application of the buried crystalline-rock concept with regard to this characteristic.

\section{Thickness and Distribution of Shale and Siltstone in the Potential Confining Unit}

The siltstone and shale confining beds found in the potential confining unit have low permeability and serve as barriers to impede vertical groundwater flow, and they have sorptive properties that tend to trap and hold contaminants. Their effectiveness as vertical-flow barriers and sorptive agents is here assumed to be directly proportional to their combined thickness.

Figure 7 shows the estimated greatest consecutive thickness of siltstones or shales that are found in the potential confining unit. East of the 100 -foot thickness line, more than half of the unit is composed of more permeable dolomite and occasional sandstone and limestone, and the confining potential of the unit here is likely to be inferior. The 
percentage of siltstone and shale increases toward the west and south and constitutes 80 percent or more of the potential confining unit in eastern Indiana and central Kentucky, where the combined thickness of these beds is greater than $500 \mathrm{ft}$. This thickening is also shown on the east-west hydrogeologic sections (plate 1 ). The areas where the combined thickness of the siltstone and shale is $500 \mathrm{ft}$ or more are considered to be the most favorable in the study area for the application of the buried crystallinerock concept with regard to the criteria of confinement.

\section{Distribution of Faults}

The steeply dipping faults that cut the Precambrian and Paleozoic rocks in the area breach the potential confining unit and may serve as hydraulic connections between the basal sandstone aquifer and the shallow freshwater aquifers. These faults, as shown in figure 3 , mainly occur on the western and southern boundaries of the study area in central Indiana, central Kentucky, and southern Ohio. The areas near these faults are considered to be least favorable for the application of the buried crystalline-rock concept.

\section{SUMMARY AND CONCLUSIONS}

This report summarizes knowledge about and makes a preliminary evaluation of the hydrogeologic suitability of the Paleozoic sedimentary rocks in the Cincinnati arch region for the disposal of high-level radioactive waste in crystalline-rock underlying the area. The area of interest includes western Ohio, eastern Indiana, and north-central Kentucky where the top of the crystalline rock lies between about 2,000 ft and 3,500 ft below sea level. The sedimentary rocks that overlie the crystalline rocks are composed of dolomite, limestone, sandstone, siltstone, and shale, and are bowed up and over a structural high in the crystalline rocks that forms a series of northeast-and northwest-striking arches. The Cambrian rocks that directly overlie the Precambrian crystalline rocks, or occur in the lower part of the sedimentary section, are of primary importance to this study. The geology and hydrology of these rocks will, in large part, control the fate of any radionuclides that might find their way into the sediment mass from a buried crystalline rock repository. 
The crystalline rocks are directly overlain by a basal sandstone aquifer that is composed of the Mount Simon Sandstone and equivalents, and sandstones in the basal parts of the Eau Claire and Rome Formations. This basal aquifer ranges from $1,000 \mathrm{ft}$ thick in the westernmost part of the area to less than $100 \mathrm{ft}$ thick in the eastern part. Porosity data are abundant and indicate that the aquifer has an average porosity of about 13 percent. Permeability data are scarce by comparison, but those that do exist indicate an average permeability of about $30 \mathrm{md}$. A few data, mostly from outside the area, indicate that horizontal to vertical permeability ratios have an average value of $25: 1$ and a median value of $4: 1$.

The basal sandstone aquifer is directly overlain by a 300 to $600-\mathrm{ft}$ stratigraphic interval that includes most of the Eau Claire, Rome and Conasauga Formations. This interval is called the potential confining unit and contains siltstones and shales with a greatest consecutive thickness that ranges from more than $500 \mathrm{ft}$ in the western and southwestern parts of the area to less than $100 \mathrm{ft}$ in the eastern and northeastern parts. The thinning of confining material toward the east is caused by the siltstones and shales of the Eau Claire Formation that change facies or grade into the dolomites and sandstones of the Rome Formation. Laboratory analyses on siltstone-shale samples collected from the Eau Claire Formation in a few wells indicate vertical permeability values that average about $1 \times 10^{-4} \mathrm{md}$.

The sedimentary rocks contain fresh ground water at depths less than $500 \mathrm{ft}$ below land surface. It is estimated that about 4 to $6 \mathrm{in}$. of the annual precipitation enters the ground-water system, and of that it is estimated that only a small part circulates deeper than $500 \mathrm{ft}$ below land surface. Available hydraulic head data are considered insufficient to determine the direction and rate of ground-water movement in the basal sandstone aquifer.

Dissolved-solids concentrations in the ground water generally increase with depth through the sedimentary section of the Cincinnati arch area and reach a maximum (brine concentrations) in the basal sandstone aquifer. Water-quality data for the basal sandstone aquifer indicate that freshwater has entered the aquifer in or near the arches area and has partly flushed the saline water from the sandstone as circulation occurred toward areas of regional discharge. 
However, in regard to deep regional ground-water circulation, only a limited relation exists between the general distribution of the dissolvedsolids concentrations in the basal aquifer and present-day major recharge and discharge areas. This limited relation is probably caused by one or more of the following factors: (1) water-quality data are too widely scattered; (2) ground water moves much greater distances horizontally than vertically before entering the basal aquifer; (3) past recharge and discharge areas were located in substantially different places from present; and (4) a larger, unknown regional flow system than the known system has been or is now operational. More detailed study is necessary to determine the importance of each of these factors.

Five general characteristics were used for the preliminary evaluation of the hydrogeologic suitability of the Paleozoic sedimentary rocks in the Cincinnait arch region for the disposal of high-level radioactive waste in crystalline rock underlying the area.

1. Depth to crystalline rock--within the constraint that the top of the crystalline rock should occur between about 1,000 and 4,000 ft below land surface, preliminary indications show the areas of potential deepest burial and thickest sedimentary rock cover occur on the periphery of the study area, the largest of which is located in eastern Indiana;

2. Distribution of dissolved-solids concentrations in the basal sandstone aquifer--the highest concentrations of dissolved solids in water in the basal sandstone aquifer, indicating slowest ground-water movement, are found on the periphery of the study area. Dissolved-solids concentrations in water exceed $250,000 \mathrm{mg} / \mathrm{L}$ in the southern part of the study area near the Kentucky-Ohio State line and in southeastern Indiana;

3. Distribution of porosity in the basal sandstone aquifer--the lowest porosity in the basal sandstone aquifer, also indicating low permeability, volume, and velocity of ground-water flow and contaminant migration, is generally found on the northern, southern, and western boundaries of the study area;

4. Thickness of shale and siltstone within the potential confining unit--the thickest consecutive confining beds, composed of siltstones and shales, that directly overlie the basal sandstone aquifer are found in 
central Kentucky and eastern Indiana where their thickness exceeds $500 \mathrm{ft}$. The thickest consecutive interval of shale and siltstone will function as the greatest impedence to vertical ground-water flow; and

5. Distribution of faults--steeply dipping faults, which may indicate potential hydraulic connections between the crystalline rock and the freshwater circulation system, occur on the western and southern boundaries of the study area in central Kentucky and central Indiana.

Collectively, these hydrogeologic data indicate that the Paleozoic sedimentary rocks in the western part of the study area are more suited for the disposal of high-level radioactive waste in underlying crystalline rock than those in the remainder of the study area.

A more detailed investigation will be necessary to test these preliminary findings and to more accurately define the geology and hydrology of the sedimentary rocks. This is particularly true with regard to the hydraulic-head and hydraulic-conductivity distribution and the direction and rate of ground-water flow in the saline-water and brine-bearing parts of the sedimentary section.

\section{REFERENCES}

American Association of Petroleum Geologists, 1978, Geological highway map-Great Lakes region, scale, 1 inch equals approximately 30 miles, 1 sheet.

Becker, L.E., Hreha, A.J., and Dawson, T.A., 1978, Pre-Knox (Cambrian) stratigraphy in Indiana: Indiana Department of Natural Resources, Geological Survey Bulletin 57, 72 p.

Bloyd, R.M., Jr., 1974, Summary appraisals of the Nation's ground-water resources--Ohio region: U.S. Geological Survey Professional Paper $813-\mathrm{A}, 41 \mathrm{p}$.

Bownocker, J.A., 1947, Geologic map of Ohio, scale 1:500,000, 1 sheet.

Bredehoeft, J.D., Bluth, C.R., White, W.A., and Maxey, G.B., 1963, Possible mechanism for concentration of brines in subsurface formations: American Association of Petroleum Geologists Bulletin, v. 47, p. $257-$ 269.

Bredehoeft, J.D., and Maini, Tidu, 1981, Strategy for radioactive waste disposal in crystalline rocks: Science, v. 213, no. 4505, p. 293-296. 
Bredehoeft, J.D., Neuzil, C.E., and Milly, P.C.D., 1983, Regional flow in the Dakota aquifer--A study of the role of confining layers: U.S. Geological Survey Water-Supply Paper 2237, 45 p.

Clifford, M.J., 1973, Hydrodynamics of Mount Simon Sandstone, Ohio and adjoining areas, in Braunstein, Jules, ed., Underground waste management and artificial recharge: Tulsa, Oklahoma, American Association of Petroleum Geologists, v. 1, p. 349-356.

Davis, R.W., 1984, Review of buried crystalline rocks of eastern United States in selected hydrogeologic environments potentially suitable for isolating high-level radioactive wastes: U.S. Geological Survey WaterResources Investigations Report 84-4091, 20 p.

Dawson, T.A., 1971, Map of Indiana showing structure on top of Trenton Limestone: Department of Natural Resources, Indiana Geological Survey Miscellaneous Map 17, scale 1:500,000.

Dever, G.R., Jr., Hoge, H.P., Hester, N.C., and Ettensohn, F.R., 1977 , Stratigraphic evidence for Late Paleozoic tectonism in northeastern Kentucky: Kentucky Geological Survey, Field Trip Guide Book, Eastern Section, American Association of Petroleum Geologists, October 9, 1976 , $80 \mathrm{p}$.

Feth, J.H., and others, 1965, Preliminary map of conterminous United States showing depth to and quality of shallowest ground water containing more than 1,000 parts per million dissolved solids: U.S. Geological survey Hydrologic Investigations Atlas HA-199, 31 p. text.

Harris, L.D., 1975, Oil and gas data from the Lower Ordovician and Cambrian rocks of the Appalachian basin: U.S. Geological Survey Miscellaneous Investigation Series Map I-917D, scale 1:2,500,000, 3 sheets.

Heath, R.C., 1983, Basic ground-water hydrology: U.S. Geological Survey Water-Supply Paper 2220, 84 p.

Heck, E.T., Hare, C.E., and Hoskins, H.A., 1964, Appalachian connate water: West Virginia Geological and Economic Survey, Bulletin 28, 42 p.

Hem, J.D., 1970, Study and interpretation of the chemical characteristics of natural waters: U.S. Geological Survey Water-Supply Paper 1473, 2d ed. $363 \mathrm{p}$.

Hopkins, H.T., 1966, Fresh-saline water interface map of Kentucky: Kentucky Geological Survey Series X, Map, scale 1:500,000.

Indiana Geological Survey, 1970, Map of Indiana showing bedrock geology: Miscellaneous Map 16, scale, 1 inch equals approximately 28 1/2 miles. 
International Association of Hydrogeologists, 1985, Hydrogeology of rocks of low permeability in Memoires, v. 1 and 2: Tuscon, Arizona, Proceedings of the 17 th Congress of the International Association of Hydrogeologists, January 7-12, 1985.

Janssens, Adriaan, 1973, Stratigraphy of the Cambrian and Lower Ordovician rocks in Ohio: Ohio Department of Natural Resources, Division of Geological Survey Bulletin 64, $197 \mathrm{p}$.

Keller, S.J., 1983, Analyses of subsurface brines of Indiana: Department of Natural Resources, Geological Survey Occasional Paper 41, $30 \mathrm{p}$.

Lamborn, R.E., 1952, Additional analyses of brines from Ohio: Ohio Department of Natural Resources, Division of Geological Survey, Report of Investigations no. 11, $56 \mathrm{p}$.

Levorsen, A.I., 1958, Geology of petroleum: W.H. Freeman and Company, San Francisco, California, 703 p.

Lloyd, O.B., Jr., Larson, J.D., and Davis, R.W., 1985, Summary of northern Atlantic Coastal Plain hydrology and its relation to disposal of highlevel radioactive waste in buried crystalline rocks--a preliminary appraisal: U.S. Geological Survey Water-Resources Investigations Report 85-4146, $80 \mathrm{p}$.

McDowel1, R.C., Grabowski, G.J., Jr., and Moore, S.L., 1981, Geologic Map of Kentucky, scale 1:250,000, 4 sheets.

McGuire, W.H., and Howell, Paul, 1963, Oil and gas possibilities of the Cambrian and Lower Ordovician in Kentucky: Lexington, Kentucky, Spindletop Research Center (for Kentucky Department of Commerce), 63 p. Neglia, S., 1979, Migration of fluids in sedimentary basins: American Association of Petroleum Geologists, v. 67, no. 4, p. 573-597.

Neuzil, C.E., Bredehoeft, J.D., and Wolff, R.G., 1982, Leakage and fracture permeability in the Cretaceous shales confining the Dakota aquifer in South Dakota, in First Annual C.V. Theis Symposium: National Water We11 Association.

ORSANCO, 1974, Registry of wells for use in underground injection of wastewater in the Ohio Valley region: Cincinnati, Ohio, Ohio River Valley Water Sanitation Commission, $101 \mathrm{p}$. 1976, Evaluation of the Ohio Valley region basal sandstone as a wastewater injection interval: Cincinnati, Ohio, Ohio River Valley Water Sanitation Commission, $30 \mathrm{p}$.

Owens, G.L., 1967, The Precambrian surface of Ohio: Ohio Department of Natural Resources, Division of Geological Survey, Report of Investigations No. 64,9 p. 1 plt. 
Pettijohn, F.J., 1975, Sedimentary rocks, third edition: New York, N.Y., Harper and Row, Publishers, Inc., $628 \mathrm{p}$.

Shaver, R.H., 1985, Correlation of stratigraphic units of North America (COSUNA) project, midwestern basin and arches region: Tulsa, Oklahoma, The American Association of Petroleum Geologists.

Stout, Wilber, Lamborn, R.E., and Schaaf, Downs, 1932, Brines of Ohio: Ohio Geological Survey, 4th series, Bulletin 37, $123 \mathrm{p}$.

U.S. Geological Survey, 1970, The national atlas of the United States of America: Arlington, Virginia, U.S. Government Printing Office, $417 \mathrm{p}$. 1980, Research on using the geohydrologic environment for isolating high-level radioactive waste: U.S. Geological Survey Yearbook, Fiscal Year 1980, p. 68-69.

1984, National Water Summary 1984--Hydrologic events, selected waterquality trends and ground-water resources: U.S. Geological Survey Water-Supply Paper 2275, 467 p.

Walker, F.H., 1980, Locations of wells that penetrated Cambrian or older units in Kentucky: Kentucky Geological Survey, map report listing wells, scale 1:500,000, 1 sheet.

Weist, W.G., Jr., 1978, Summary appraisals of the nation's ground-water resources--Great Lakes region: U.S. Geological Survey Professional Paper 813-J, $30 \mathrm{p}$. 


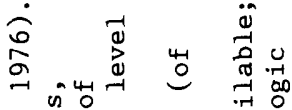

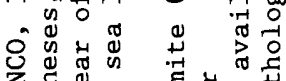

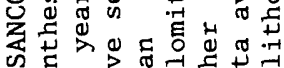

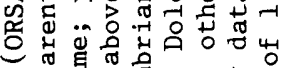

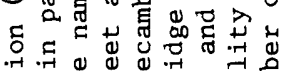

年

1)

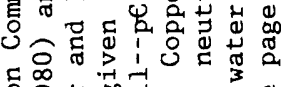

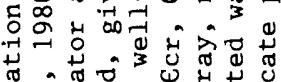

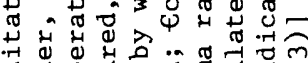

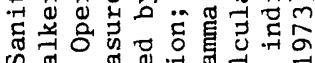

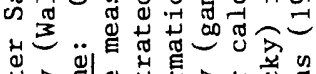

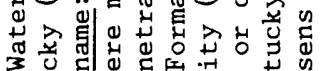

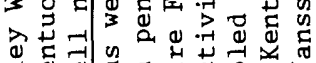

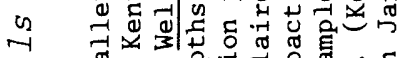

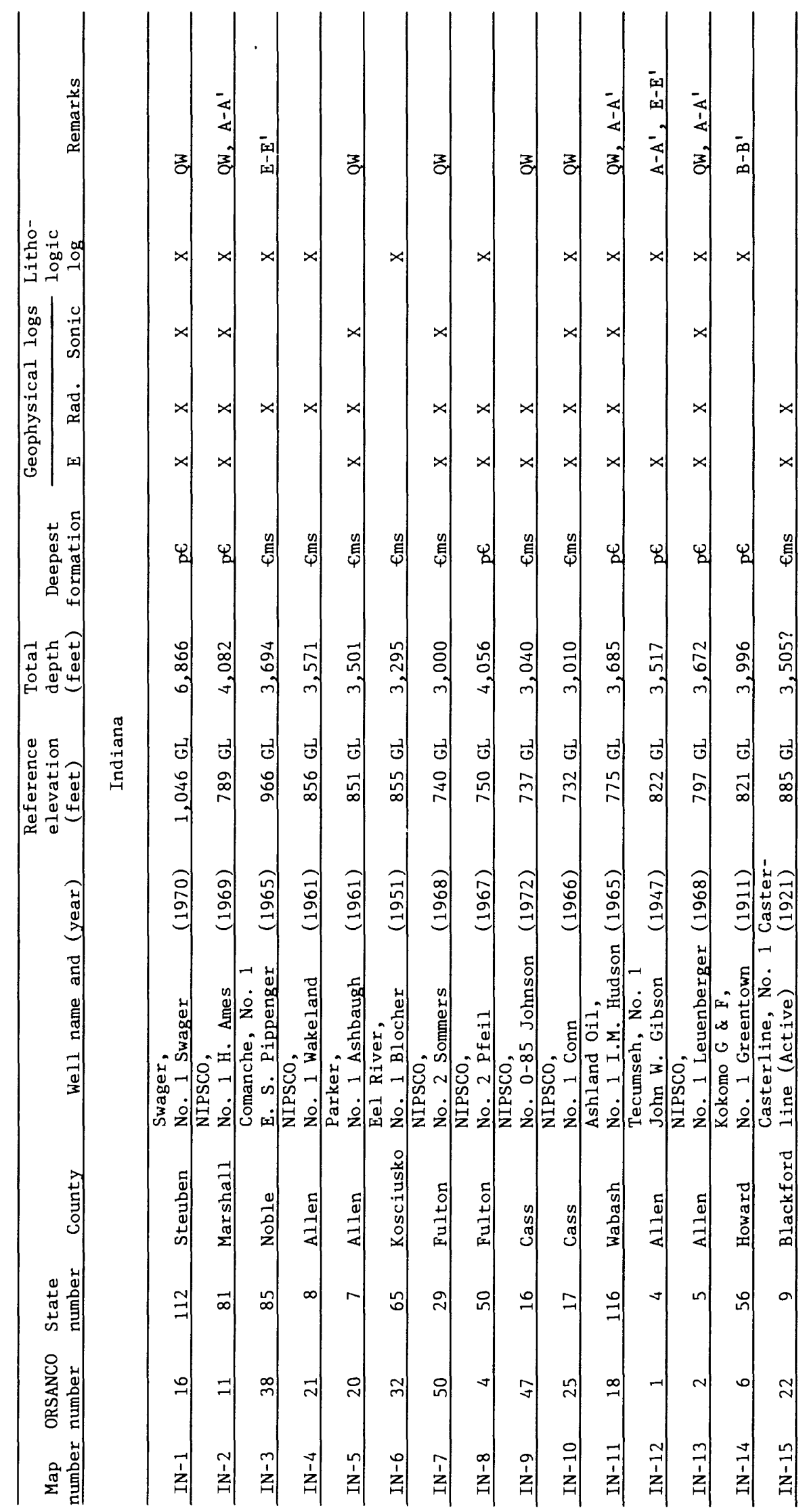

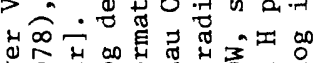

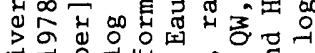

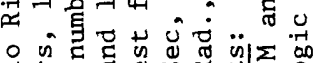

出

>

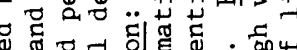

कू⿻

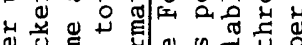

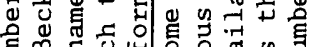

然

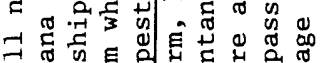

(⿻)

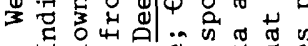

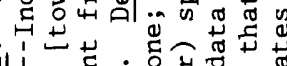

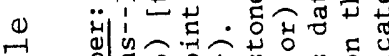

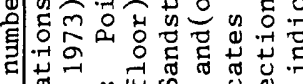

o 0 in

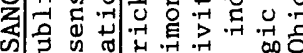

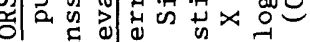

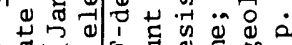

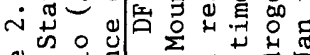

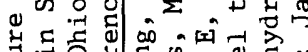

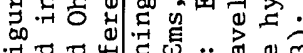

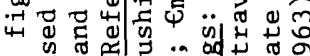

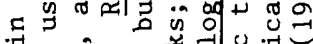

मे

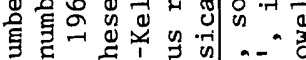

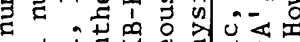

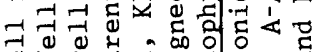

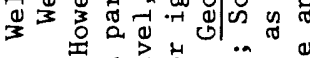

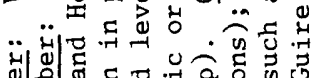

\&

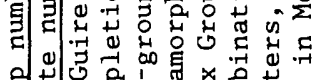

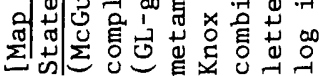




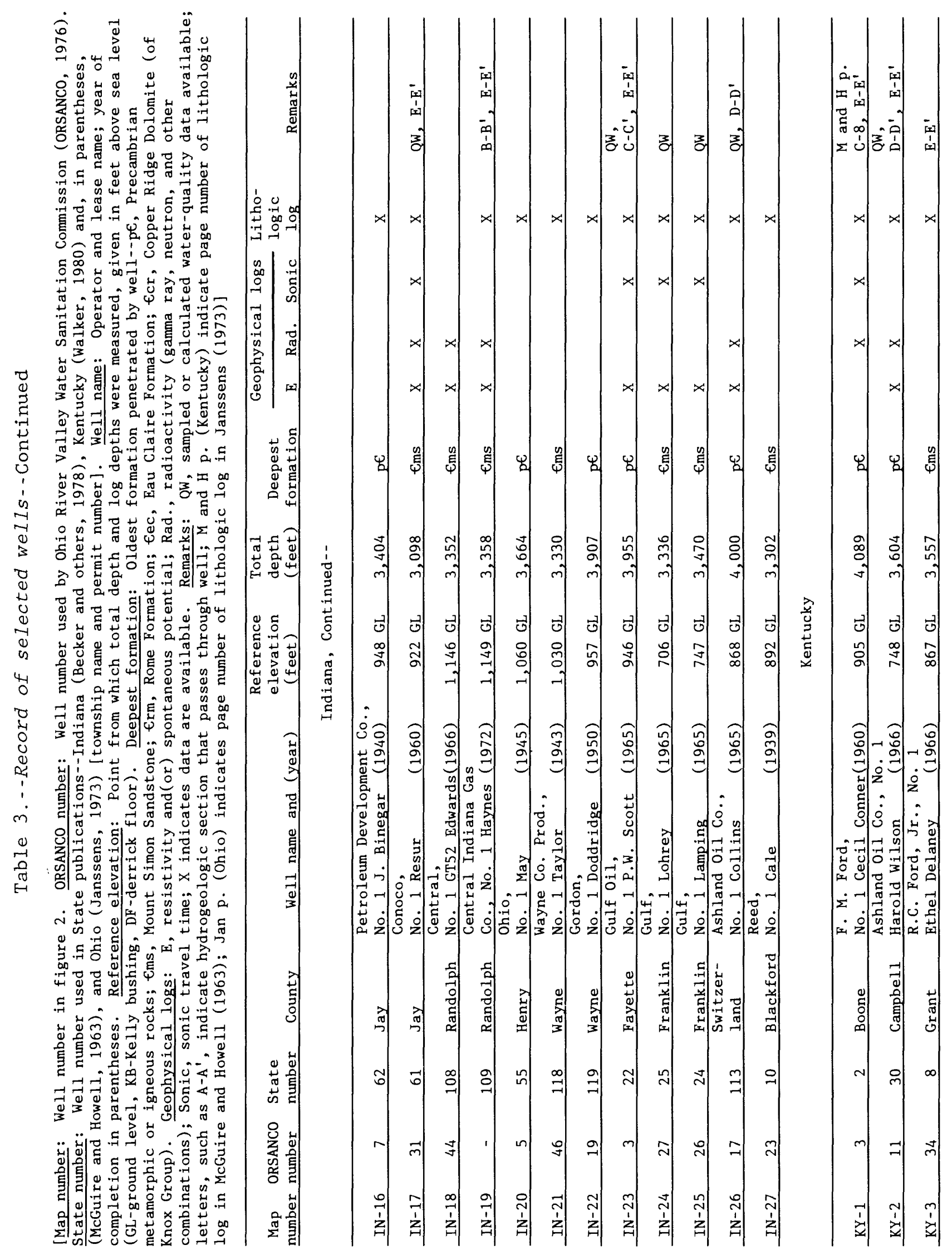




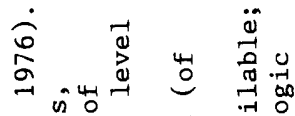

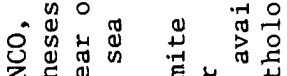

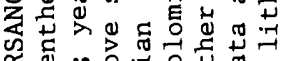

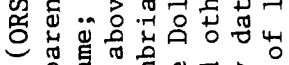

. . .

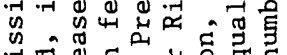

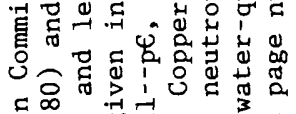

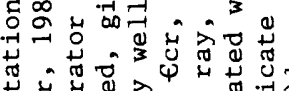

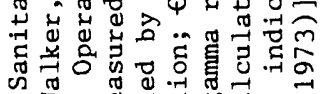

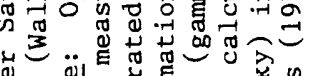

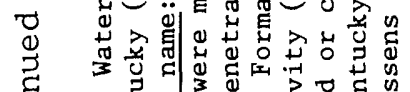

엉 of

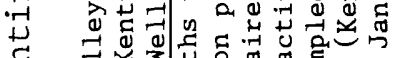

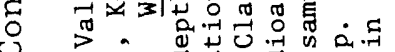

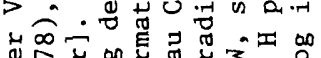

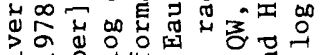

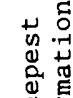

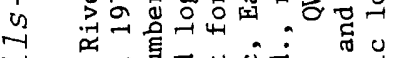

代

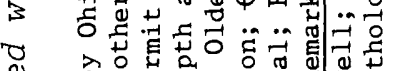

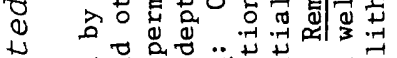

仓

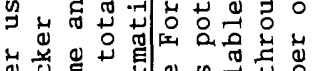

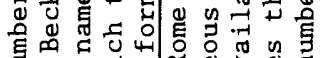

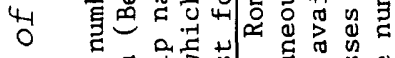

可 न

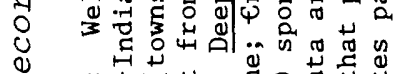

Q

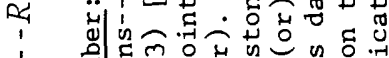

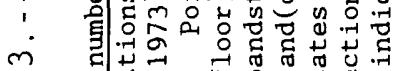

0

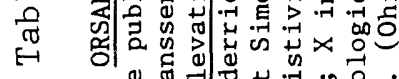

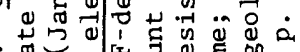

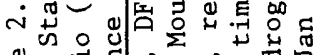

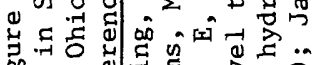

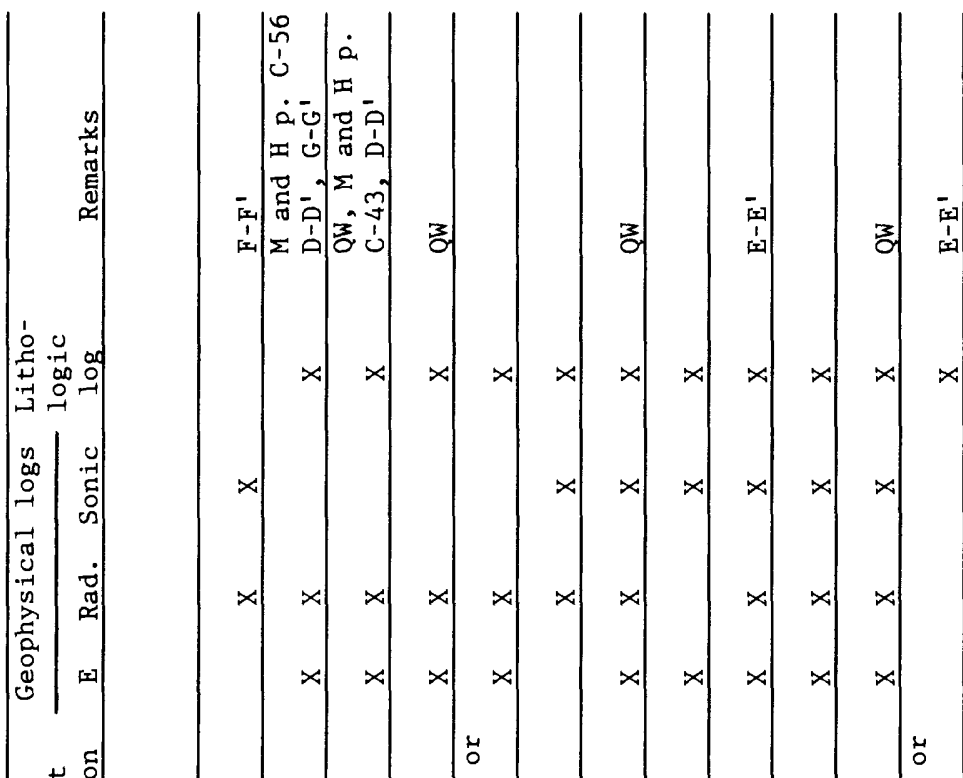

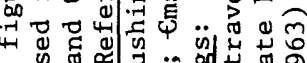

동

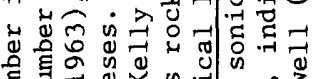

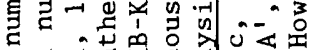

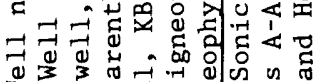

a

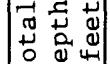

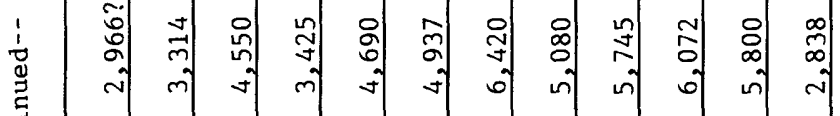

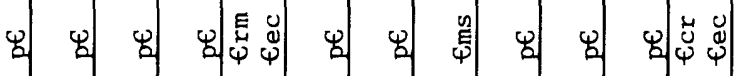

近

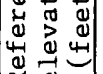

ठ

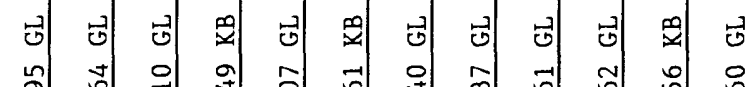

f

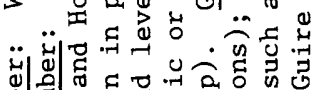

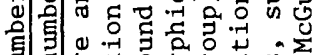

a 90

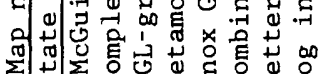

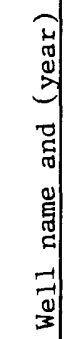

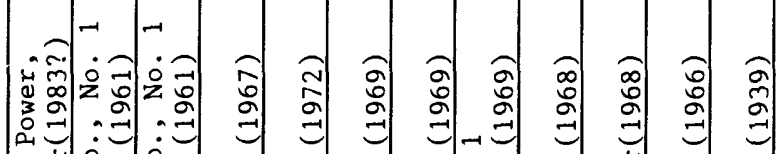

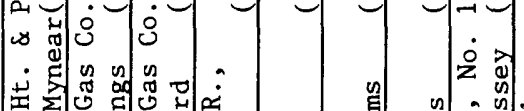

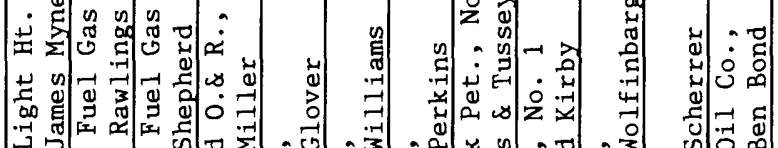

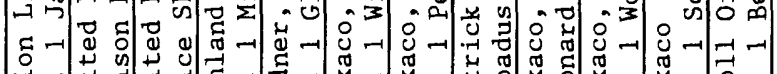

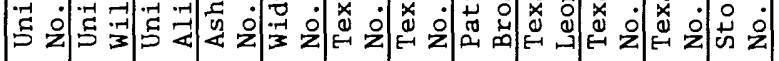

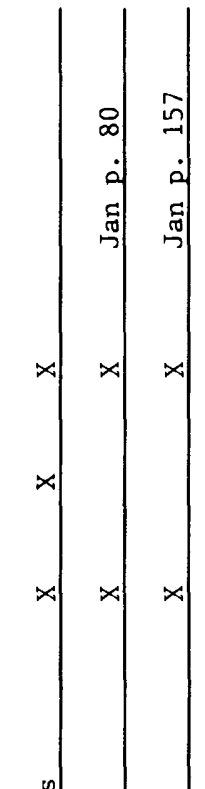

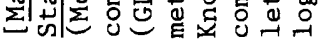

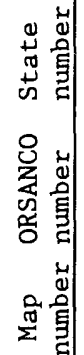

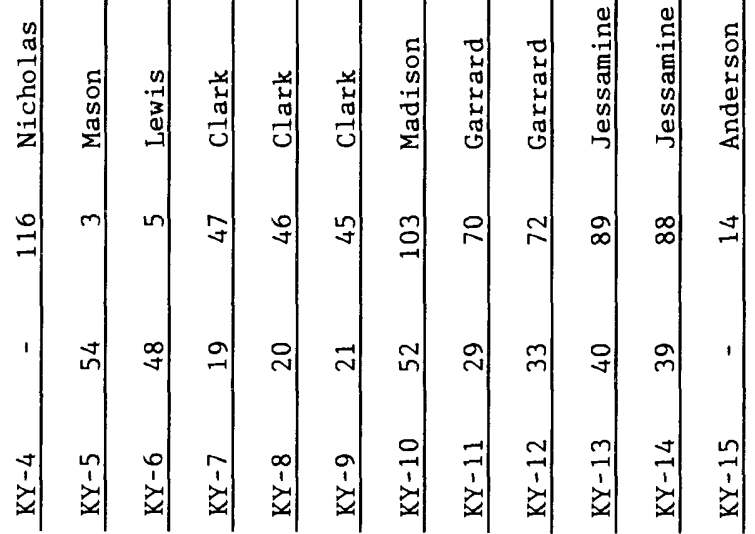

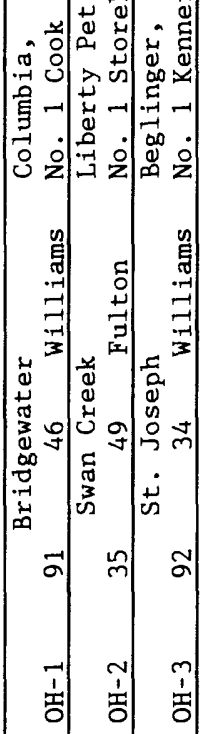




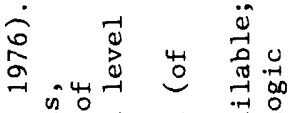

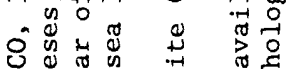

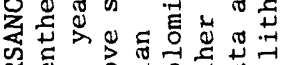

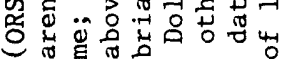

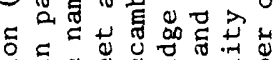

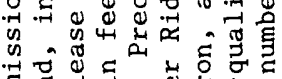

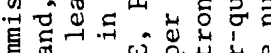

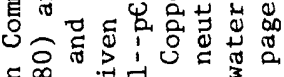
5

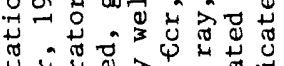

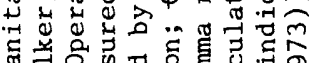
is 70 if

ه

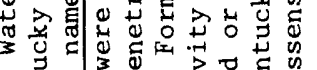

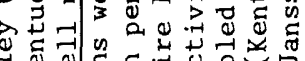

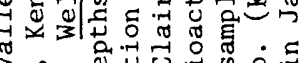

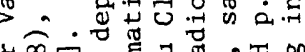

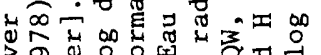
元 을

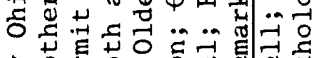

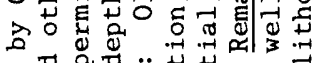

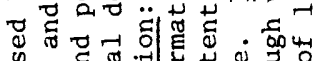

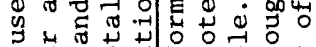
म ن 造

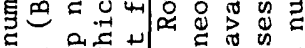

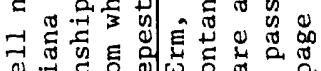
उ $\rightarrow$ है 舟 计落.

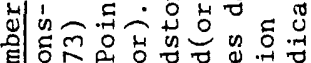

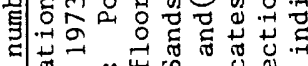
0 .

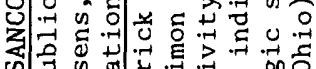

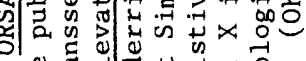
의

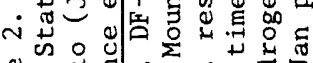
도응 政

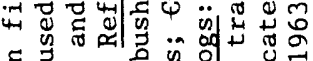

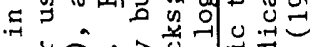
मूँ

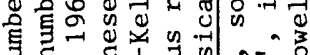
等

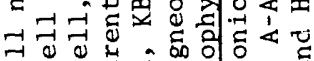

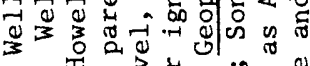

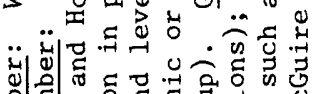
然。 ํ.

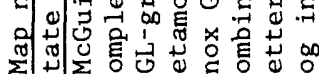

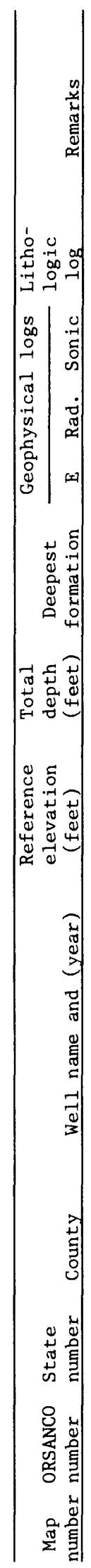

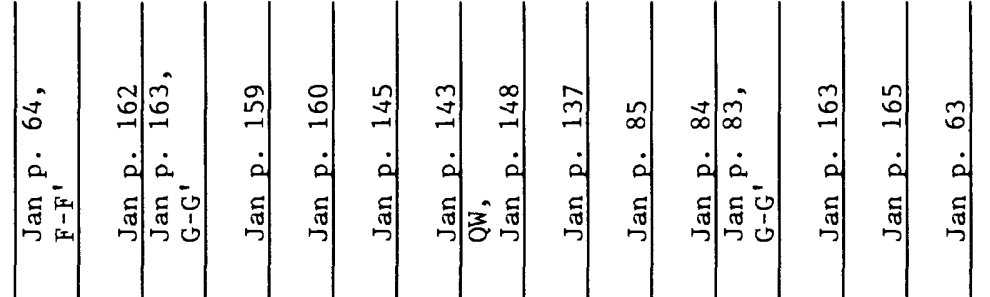
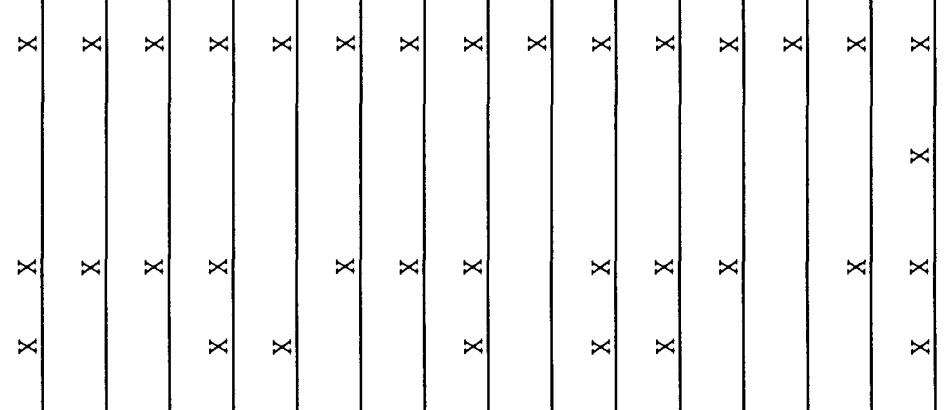

फे कै

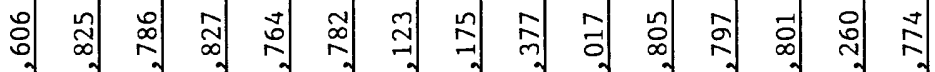

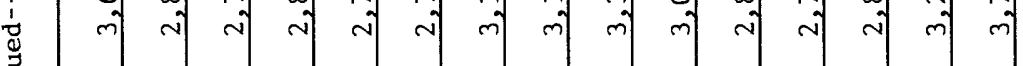

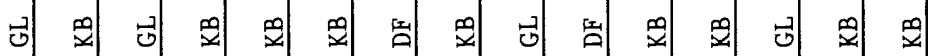

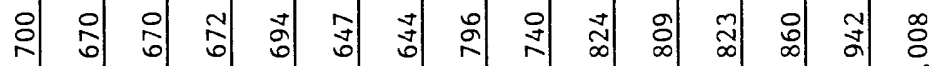

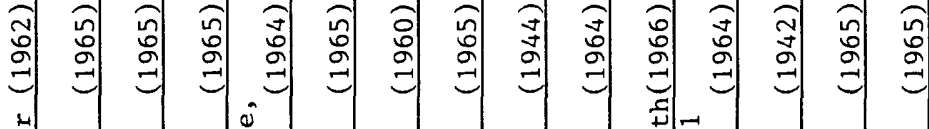

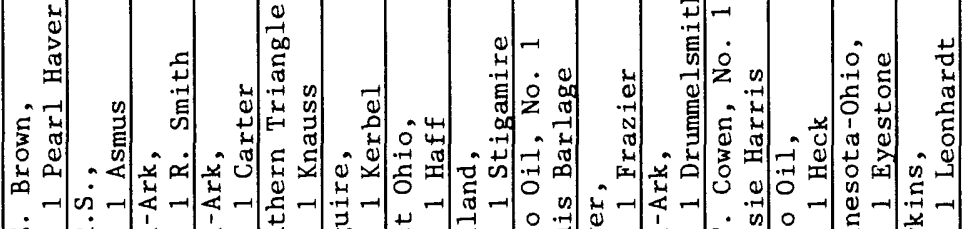

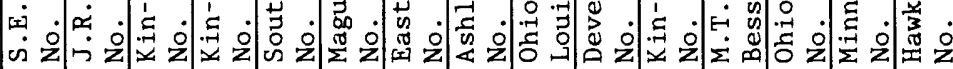

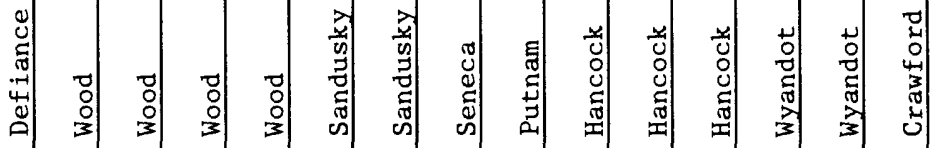

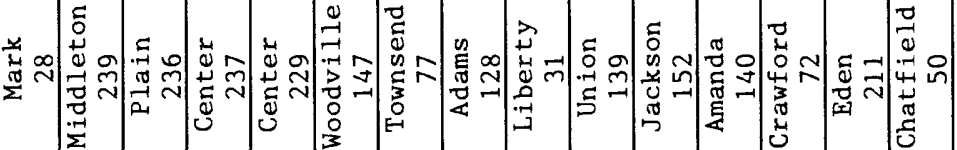

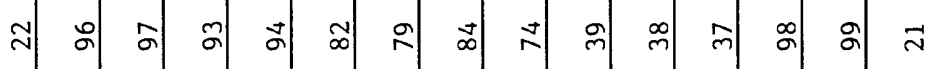

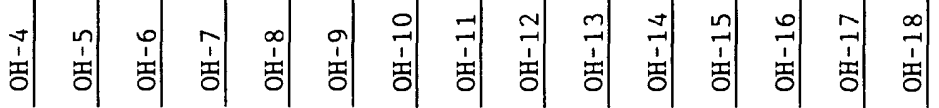




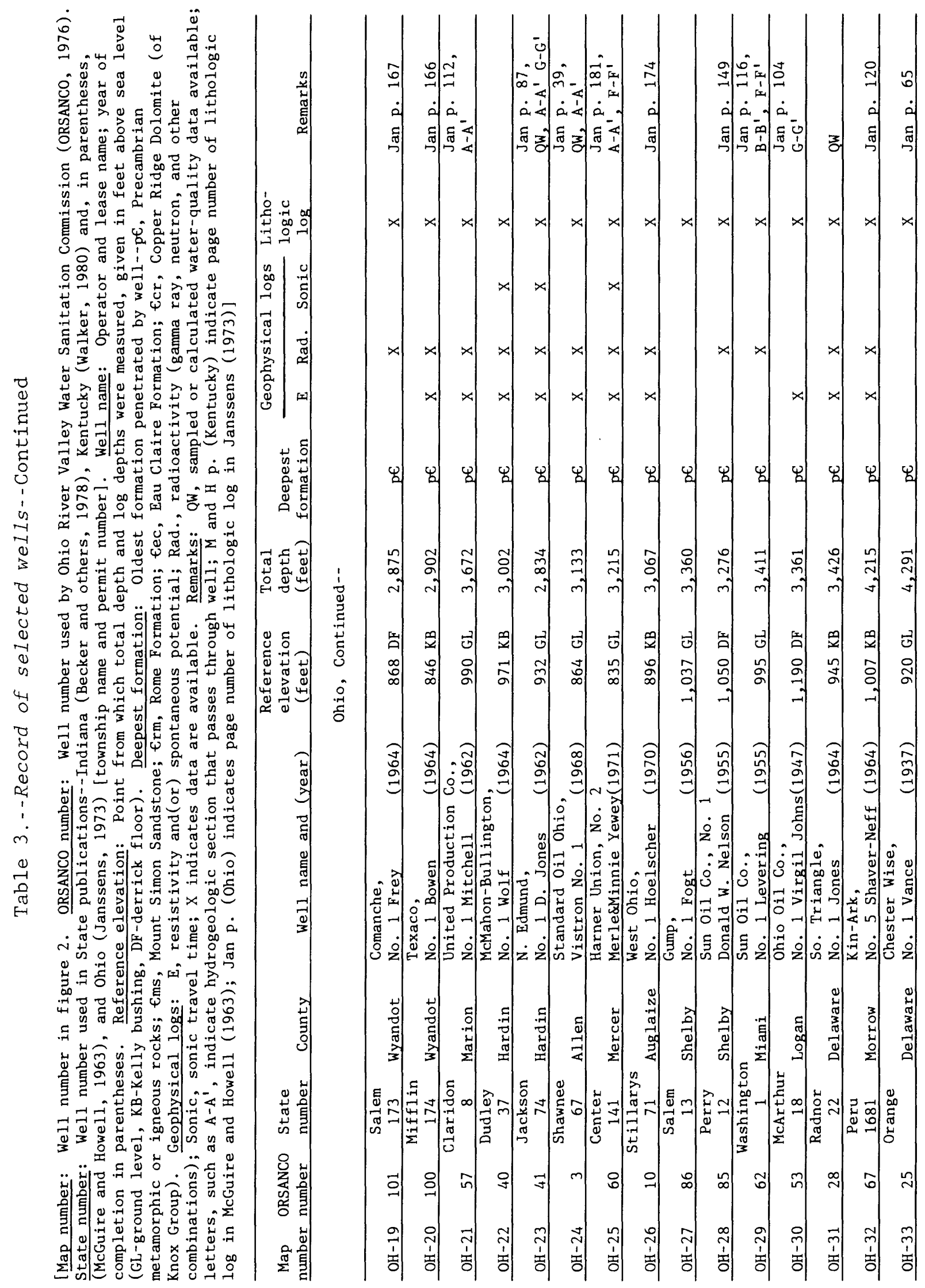




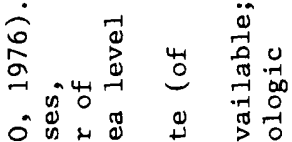

Oํ.

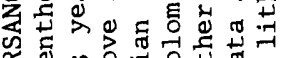

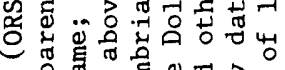

ह

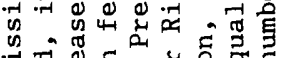

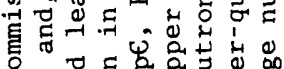

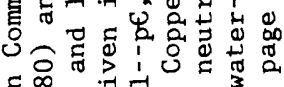

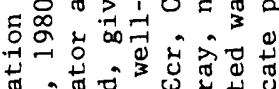

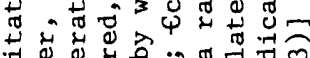

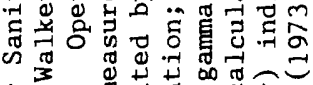

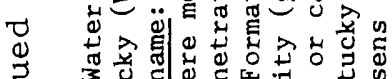

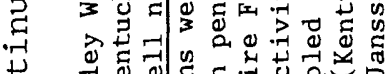

若

क人

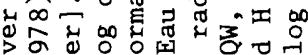

a

计

3 ठ

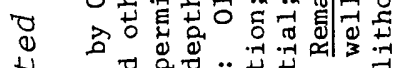

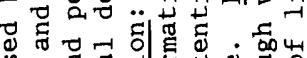

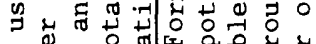

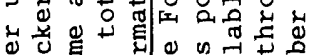

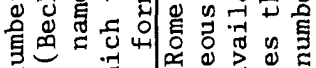

$=2 \frac{1}{3}+20$

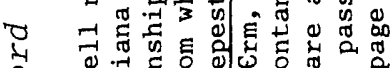

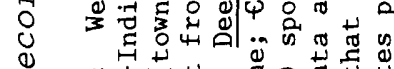

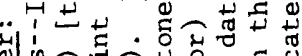

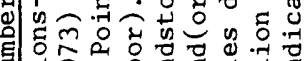

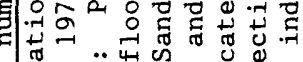

$m$ 可

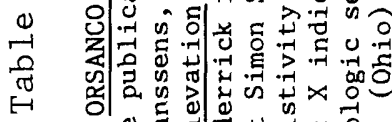

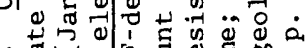

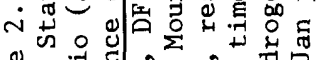
牙击

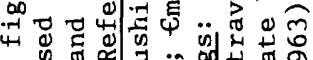

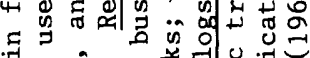

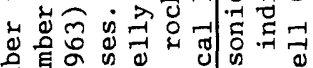

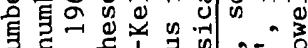

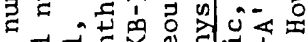
न न7 न न

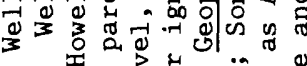

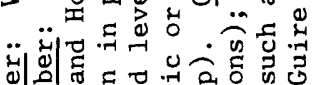

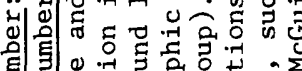

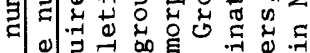

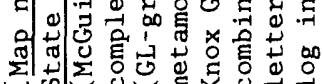

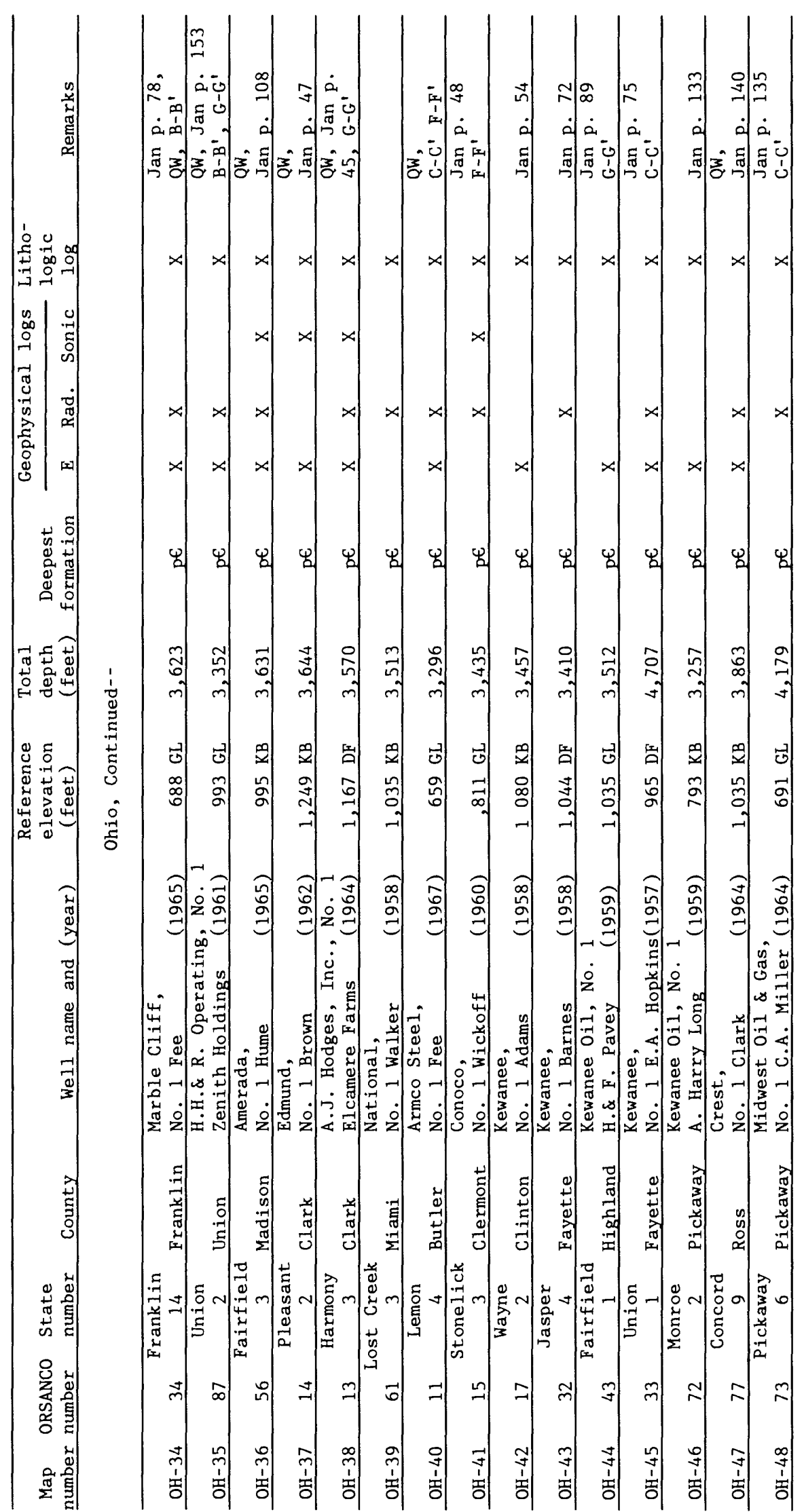

